\title{
Short sisal fiber reinforced recycled concrete block for one-way
} precast concrete slabs

\author{
Paulo R. L. Lima ${ }^{1, *}$, Joaquim A. O. Barros ${ }^{2}$, Alex B. Roque ${ }^{1}$, Cintia M. A. Fontes ${ }^{1}$, José M. F. Lima ${ }^{1}$
}

${ }^{1}$ Department of Technology, Civil and Environmental Program, State University of Feira de Santana, Feira de Santana, Bahia, Brazil, e-mail: lima.prl.uefs@gmail.com (corresponding author).

${ }^{2}$ ISISE, Department of Civil Engineering, University of Minho, Guimarães, Portugal, e-mail: barros@ civil.uminho.pt.

${ }^{*}$ Corresponding author

\section{Abstract}

This work is dedicated to the assessment of the structural capacity of a new lightweight block for one-way precast concrete slabs made of short sisal fiber reinforced concrete (SSFRC) containing natural and recycled aggregate. Flexural tests were carried out on SSFRC block samples, as well as on ceramic and EPS blocks used commercially. Slab panels including SSFRC, ceramic and EPS blocks were tested under four point bending configuration to assess the benefits of the new SSFRC block in quasi-real slab conditions. The results of the tests indicated the influence of the sisal fibers and recycled aggregate on the physical and mechanical properties of the concrete and the best structural performance of the SSFRC blocks in relation to commercial solutions. The flexural behavior and cracking of slabs were presented and discussed. Numerical models were also developed to predict the nonlinear behavior of the SSFRC and to simulate the flexural behavior, crack initiation and propagation in the blocks. By adopting this numerical strategy, a parametric study was carried out to simulated new design of blocks and to demonstrate that the load carrying capacity at serviceability limit state conditions can be significantly increased with the thickness of SSFRC block.

Keywords: sisal fiber, recycled aggregate, concrete block, one-way slab, finite element method

\section{1 - Introduction}

In less developed and in overpopulated countries, the need to reduce the consumption of non-renewable natural resources and energy has encouraged the development of low cost, safe and sustainable constructive solutions, such is the case of affordable houses [1]. This strategy requires the use of local raw and renewable materials, recycled 
constituents according to a methodology that mobilizes effectively their properties, which is being pursued by several researchers in diverse countries like Malaysia, India and China [2]. By using the prefabrication technology, these materials can be applied on the development of lightweight and durable constructive components according to suitable standards of quality control for the building of modular houses.

One way precast concrete slabs are used in United States since the 1950s, being composed by longitudinal prefabricated concrete slender beams reinforced by passive or prestressed steel wires, lightweight blocks (that can be made by diverse types of materials) supported in these beams, and concrete cover layer cast in place. This slab is the most popular flooring system for residential buildings in several countries [3, 4]. The simple and fast method of executing, lightness and relatively low cost make them highly competitive, since the use of formworks is avoided, and the requirements for skilled manpower and time construction are reduced. The lightweight character of this type of slabs, currently designated by "beam-and-block floor system - B\&B-FS" [5] is caused by the application of the aforementioned blocks. Therefore, the permanent loads transferred to their supports (beams and columns) and foundations are smaller than when massive RC slabs (heavier) are used [6], with consequent benefits in terms of the costs of these other constructive elements and better response of the building under seismic events.

In environmental terms, the comparative life cycle analysis (LCA) performed by LópezMesa et al. [4], where the local construction practices adopted in Spain were considered, has indicated that the B\&B-FS has lower environmental impact than in situ cast floors for residential buildings.

Despite the numerous advantages of the B\&B-FS, some problems have been identified in its execution, mainly due to the susceptibility of the blocks to premature failure during the assembly process of the system, when the concrete cover is being cast, or during the installation of the housing infrastructures [3]. Despite the existence of quality control standards for the mechanical strength requisites of these blocks, a program for the assessment of their properties have indicated values below the minimum limit imposed by these standards [7].

Numerous types of blocks are commercially available for B\&B-FS, being clay, concrete and expanded polystyrene (EPS) the most used materials. In Brazil, the main lightweight blocks are made in clay and in EPS, with a share market of $55 \%$ and $85 \%$, respectively [8]. To avoid the deficiencies, and to increase the sustainability of B\&B- 
FS, some initiatives are being done to use new materials for the blocks. In this regards, Milicevic et al. [9] have demonstrated the possibility of replacing $50 \%$ of fine aggregates and $75 \%$ of coarse aggregates by recycled ceramic aggregates for producing concrete blocks for B\&B-FS with mechanical, acoustic and thermal properties suitable for this slab system. By using recycled materials, from recyclable PET bottles, aluminum cans and Tetra Pak cartons in the substitution of conventional materials in blocks for semi-precast slabs, Vargas et al. [10] investigated the economic viability of the developed slab systems. However, the individual recycled blocks were not mechanically evaluated and certainly did not show required strength for use in situ. The use of autoclaved aerated concrete blocks in precast concrete slab with ferrocement permanent formwork was evaluated by [11]. After having executed flexural test with this type of slabs, the authors verified that the dead weight of this type of slabs is 32$23 \%$ less than the one of solid reinforced concrete slab. Similar test was carried out using brick masonry as a lightweight block [12]. This construction system presented acceptable mechanical performance, with crack patterns similar to those observed in reinforced concrete one way slab. Blocks from recycled plastic from municipal waste were also used in the construction of two store building [13]. In comparison to a full reinforced concrete slab, the reduction of the slab's deadweight was $38 \%$, and the reduction of concrete consumption was $43 \%$.

A review on the use of fiber-reinforced concrete (FRC) in precast concrete applications was performed by Banthia et al. [14]. FRC, where steel and glass fibers were adopted, was successfully used in formworks for beams and lightweight panels. Permanent formworks made by strain hardening cementitious composites reinforced with PVA fibers was produced [15], as an alternative approach for the construction of more durable slabs and beams of reinforced concrete, and their contribution provide an increase in the load capacity of these elements. The use of sisal fiber as reinforcement of permanent formwork for slabs was evaluated by Schafer and Brunssen [16]. Arch and trapezoidal shape elements with a thickness of 10 to $20 \mathrm{~mm}$ were produced with laminated composites reinforced with long sisal fiber layers. The load-deflection test of arch type formwork was characterized by a flexural hardening behavior with a maximum load twice higher than first crack load, and a failure load of about $7 \mathrm{kN}$ was obtained, which guarantees a high safety factor for all loading cases that may arise during the casting and construction process of this type of slab. According to these authors, however, the manufacturing procedure of this type of formwork is very labor- 
intensive and, of course, inappropriate for large scale production. In fact, despite the excellent performance of long sisal fiber cement based composites under bending [17, 18], the lamination process requires advanced production techniques, in comparison with used technique on the production of concrete reinforced with short fibers.

A wider application of sisal-cement composites can be achieved with the use of short fibers dispersed in the matrix, due to ease of molding since it is based on the traditional method of concrete production. In past, many roofing tiles were produced with short vegetable fibers using conventional concrete technology, but the poor performance with rupture after 6 months finished its use [19]. Recent studies, however, have shown that the use of short randomly distributed sisal fibers can result in composites having flexural hardening if appropriate measures are used in the production of the matrix and fiber treatment. According [20] the hornification of sisal fiber by executing wetting and drying cycles provides a better fiber-matrix bonding behavior and an increase of $40 \%$ on the bond strength. In fact, composites reinforced with $4 \%$ and $6 \%$ of treated fibers of $50 \mathrm{~mm}$ length $\left(l_{f}\right)$ presented a multiple cracking behavior with deflection hardening. The binder of this material was composed of Portland cement and high content of both metakaolin and fly ash to guarantee the durability of the sisal fiber and also to ensure an adequate workability to the matrix for a proper fiber dispersion. Lima et al. [21] used similar binder, but replaced part of natural aggregate by recycled concrete aggregate. The produced self-compacting matrix allowed a more homogeneous material reinforced with $40 \mathrm{~mm}$ fiber length, having been registered a flexural hardening behavior with multiple cracking and small cracking space. Due to these characteristics, the application of this material for roof constructive element was numerically evaluated, having been demonstrated high potentialities for this type of application [22].

To evaluate the potential use of cementitious materials reinforced with short vegetable fibers (herein designated by the acronym SSFRC) in the production of lightweight blocks for precast concrete slabs, a new block was designed, manufactured and tested experimentally in this work. The self-compacting matrix was produced with recycled aggregate and substituting part of cement by silica fume and fly ash. The mechanical performance of the developed block was evaluated according to the Brazilian standard for this type of constructive elements, and compared with the one of blocks made by traditional materials, such as ceramic and EPS. Slab panels including SSFRC, ceramic and EPS blocks were tested under four point bending configuration to assess the benefits of the new SSFRC block in quasi-real slab conditions. Material nonlinear 
analysis with a software capable of simulating the crack initiation and propagation were carried to explore the potentialities of SSFRC for this type of blocks by executing parametric studies after the good predictive performance of the constitutive model has been assessed by simulating the experimental tests carried out.

\section{Experimental Program}

\subsection{Materials}

\section{Processing and characterization of sisal fiber}

The sisal plant (Figure 1a) is a member of the plant family of agavaceae that is indigenous of the arid zones of America. The plant is characterized by leaves that can exceed one meter length composed by long and very strong fibers. Harvesting is carried out by hand. After harvesting, the leaves are transported to a machine localized, in general, at plantation (Figure 1b) and decorticated to extract the cortex of ribbon fibers that run along the length of the leaves (Figure 1c).
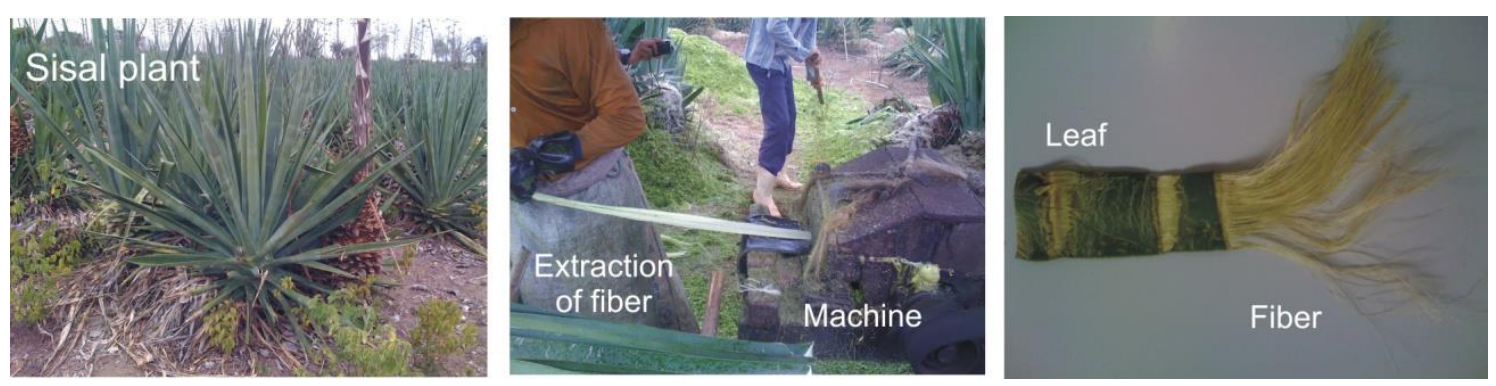

Fig. 1. Extraction of vegetable fiber: a) sisal plant; b) fiber decortification process; b) identification of sisal fiber in leaf

The sisal fibers used in this research were collected in the city of Valente, state of Bahia - Brazil. Initially, the fibers were washed in hot water $\left(50{ }^{\circ} \mathrm{C}\right)$ to remove surface soluble extractives [23]. The fiber treatment was conducted according [20], and consisted in immersing the fibers in water $\left(\mathrm{T} \sim 23{ }^{\circ} \mathrm{C}\right)$ and their removal after saturation $(3 \mathrm{~h})$ for drying in a furnace at a temperature of $80^{\circ} \mathrm{C}$ (16 hours). This procedure was repeated 10 times. According previous results [24] this treatment permits an increase of fiber-matrix bond performance, and the decrease of dimensional variation of sisal fiber due to variation of moisture.

Fiber tensile tests indicate that the used fiber have a tensile strength of $353 \mathrm{MPa}$ and an elastic modulus of $15.72 \mathrm{GPa}$ [25]. 
167 Concrete waste provenient from a building demolition site at Feira de Santana 168 (Northeast of Brazil) was used to produce the recycled aggregate. After crushing, the waste was screened in sieve of $2.36 \mathrm{~mm}$ to produce the fine recycled concrete aggregate (RA) used in this work. Mineralogical and morphological properties of recycled aggregate have been carried out in a previous work [26]. The natural aggregate used as reference to recycled aggregate was a fine sand (NA). Granulometry and physical properties of the aggregate are shown in Table 1. As expected, the recycled aggregate presented higher presence of materials finer than $150 \mu \mathrm{m}$, which is attributed to the crushing process of obtaining aggregates. The water absorption of about $6 \%$ is in accordance with the values observed by [27].

Table 1

Characterization of aggregates

\begin{tabular}{lll}
\hline Characteristic & $\begin{array}{l}\text { Natural } \\
\text { aggregate } \\
\text { (NA) }\end{array}$ & $\begin{array}{l}\text { Recycled } \\
\text { aggregate } \\
\text { (RA) }\end{array}$ \\
\hline Maximum diameter $(\mathrm{mm})$ & 1.20 & 2.36 \\
\hline Fineness & 1.73 & 2.11 \\
\hline $\begin{array}{l}\text { Materials finer than } 150 \mu \mathrm{m} \\
(\%)\end{array}$ & 0.95 & 14.36 \\
\hline Absorption $(\%)$ & 0.03 & 6.11 \\
\hline Unit weight $\left(\mathrm{kg} / \mathrm{dm}^{3}\right)$ & 2.65 & 2.60 \\
\hline
\end{tabular}

180

181

182

183

184

185

186

187

188

189

190

191

192

\section{Binder constituents}

In order to obtain a durable composite, whose matrix does not chemically attack the sisal fiber, and with adequate rheology, the binder constituents used were composed of cement CP V ARI (ASTM Type III), suitable for production of prefabricated element, and two mineral additions: $40 \%$ of fly ash and $10 \%$ of silica fume as partial cement substitutions.

In accordance with Gram [19], the use of the fume silica ensures a higher consume of the calcium hydroxides produced by the reaction of the cement hydration, which prevents the mineralization of the vegetable fiber and reduces the $\mathrm{pH}$ of the matrix, avoiding the alkaline hydrolysis. The efficiency of the addition of silica in improving the durability of cement based composites reinforced with vegetable fibers was confirmed by others authors [28, 29]. 
Table 2 shows the characteristics of the binder constituents. According to ASTM C618

194 [30], the fly ash (FA) and silica fume (SF) can be classified as pozzolanic material since 195 the sum of three oxides from its chemical analyses, $\mathrm{SiO}_{2}+\mathrm{Al}_{3} \mathrm{O}_{3}+\mathrm{Fe}_{2} \mathrm{O}_{3}$, were higher 196 than 70\%. Thermogravimetric (TG) analysis, shown in Figure 2, was performed in 197 cement paste and blended cement paste after 28 days of cure to evaluate the calcium 198 hydroxide content. The identification of the main hydrated and carbonated phases can 199 be better visualized by the peaks of the TG derivative (DTG), which corresponds to the 200 several steps of mass loss. It can be seen that for both pastes, at temperature below $100^{\circ}$ 201 C the DTG peak indicates a loss of combined water, which comes initially from the 202 calcium silicate hydrate $(\mathrm{C}-\mathrm{S}-\mathrm{H})$ and then from ettringite. For the cement paste, Figure 2032 shows that a significant peak of calcium hydroxide, $\mathrm{Ca}(\mathrm{OH})_{2}$, decomposition has 204 occurred between $400^{\circ} \mathrm{C}$ and $480^{\circ} \mathrm{C}$ (due to a free lime content), while a smaller peak was visible at $650^{\circ} \mathrm{C}$ due to the $\mathrm{CO}_{2}$ released during calcium carbonate $\left(\mathrm{CaCO}_{3}\right)$ decomposition. The weight losses between $400^{\circ} \mathrm{C}$ and $480^{\circ} \mathrm{C}$ obtained from the TG curves allow calculating the calcium hydroxide content. In DTG curves of blended paste, the peak of calcium hydroxide decomposition was practically absent because it was almost totally consumed during pozzolanic reactions.

Table 2

Binder constituents

\begin{tabular}{|c|c|c|c|c|}
\hline \multicolumn{2}{|l|}{ Characteristics } & \multirow{2}{*}{$\frac{\text { Cement }}{69.77}$} & \multirow{2}{*}{$\frac{\text { Fly ash (FA) }}{2.06}$} & \multirow{2}{*}{$\begin{array}{c}\text { Silica Fume (SF) } \\
0.17\end{array}$} \\
\hline \multirow{6}{*}{$\begin{array}{l}\text { Major chemical } \\
\text { component }(\%)\end{array}$} & $\mathrm{CaO}$ & & & \\
\hline & $\mathrm{SiO}_{2}$ & 15.89 & 53.33 & 95.3 \\
\hline & $\mathrm{SO}_{3}$ & 4.76 & 1.51 & - \\
\hline & $\mathrm{Al}_{2} \mathrm{O}_{3}$ & 4.35 & 33.23 & 0.04 \\
\hline & $\mathrm{K}_{2} \mathrm{O}$ & 1.07 & 3.44 & 1.33 \\
\hline & $\mathrm{Fe}_{2} \mathrm{O}_{3}$ & 3.66 & 4.96 & 0.35 \\
\hline \multicolumn{2}{|c|}{ Specific gravity $\left(\mathrm{g} / \mathrm{cm}^{3}\right)$} & 3.06 & 2.01 & 2.65 \\
\hline
\end{tabular}




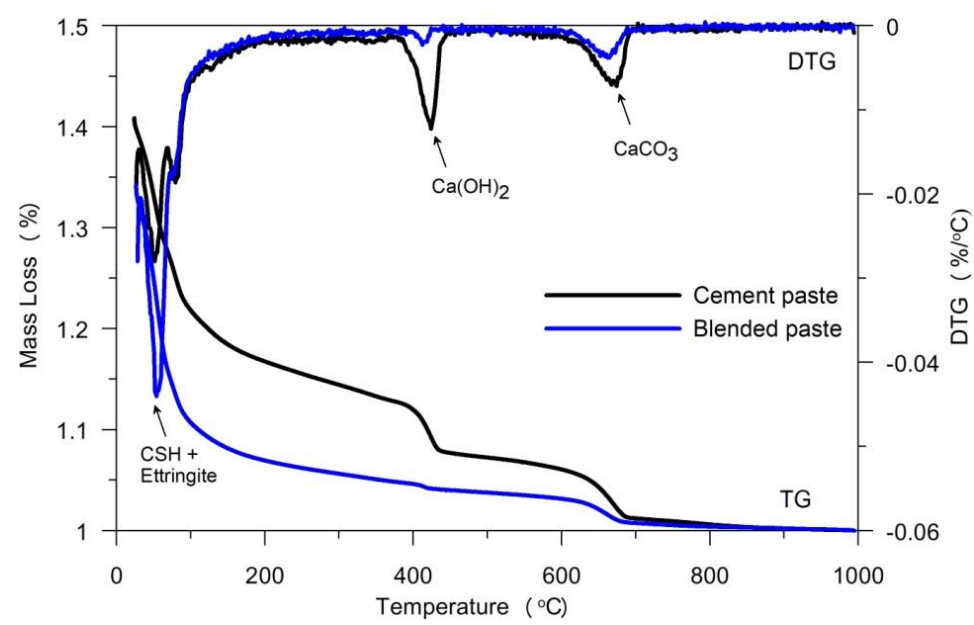

Fig. 2. TG and DTG curves of the cement paste and of the blended paste after 28 days of cure.

\section{Composite production}

The concrete in the proportion of 1:1:0.35 (binder:sand:water/binder ratio, by weight), were prepared with the use of natural aggregate (NA) and recycled aggregate (RA) in two combinations: $100 \%$ NA (plain concrete) and $80 \%$ of NA $+20 \%$ of RA (plain recycled concrete). Fiber reinforced concretes with $6 \%$, in mass, of sisal fiber were produced using similar combinations of aggregates, as shown in Table 3.

Table 3

Mix proportions matrices and composites $\left(\mathrm{kg} / \mathrm{m}^{3}\right)$

\begin{tabular}{|c|c|c|c|c|c|}
\hline \multicolumn{2}{|c|}{ Components } & \multirow{2}{*}{$\begin{array}{c}\begin{array}{c}\text { Plain } \\
\text { Concrete } \\
\text { (PC) }\end{array} \\
437.6\end{array}$} & \multirow{2}{*}{$\begin{array}{c}\begin{array}{c}\text { Plain } \\
\text { Recycled } \\
\text { Concrete } \\
\text { (PRC) }\end{array} \\
437.1\end{array}$} & \multirow{2}{*}{$\begin{array}{c}\begin{array}{c}\text { Fiber } \\
\text { Reinforced } \\
\text { Concrete } \\
\text { (FRC) }\end{array} \\
413.4\end{array}$} & \multirow{2}{*}{$\begin{array}{c}\begin{array}{c}\text { Fiber Reinforced } \\
\text { Recycled } \\
\text { Concrete (FRRC) }\end{array} \\
413.1\end{array}$} \\
\hline \multirow{3}{*}{$\begin{array}{l}\text { Binder } \\
\text { constituents }\end{array}$} & Cement & & & & \\
\hline & Silica of fume & 87.5 & 87.4 & 82.7 & 82.6 \\
\hline & Fly ash & 350.1 & 349.7 & 330.8 & 330.4 \\
\hline \multirow{2}{*}{ Aggregates } & Natural & 875.1 & 699.4 & 826.9 & 660.9 \\
\hline & Recycled & - & 174.8 & - & 165.2 \\
\hline \multirow[b]{2}{*}{ Additives } & Plasticizer & 23.3 & 37.9 & 55.1 & 90.9 \\
\hline & $\begin{array}{c}\text { Viscosity } \\
\text { agent }\end{array}$ & 0.61 & 0.62 & 0.83 & 0.83 \\
\hline \multicolumn{2}{|c|}{ Water } & 290.0 & 279.5 & 250.8 & 225.5 \\
\hline \multicolumn{2}{|c|}{ Fiber } & - & - & 49.6 & 49.5 \\
\hline
\end{tabular}

228 Since the water absorption rate of recycled aggregate is larger than natural aggregate

229 (see Table 1), a superplasticizer (SP) was added to the mixtures to avoid major 230 modification on the water/cement ratio, and to ensure a self-compacting behaviour for 231 all matrices. A third generation superplasticizer (Glenium 51) with a solid content of $23230.9 \%$ and specific gravity of $1.1 \mathrm{~g} / \mathrm{cm}^{3}$ was used. The viscosity modifier admixture 233 (VMA) Rheomac UW 410, with specific gravity of $0.7 \mathrm{~g} / \mathrm{cm}^{3}$, at a dosage of $0.05 \%$ 
relative to the binder, in weight, was also used in order to avoid segregation during molding.

The flow table test [31] was carried out to determine the consistency of the materials (Figure 3). A spreading of $270 \pm 10 \mathrm{~mm}$ was observed for fiber cement composites. In the case of the self-compacting matrices a spreading of $400 \pm 10 \mathrm{~mm}$ was measured after mold removal without application of drops in the flow table, indicating the high flowability of matrix.

a)
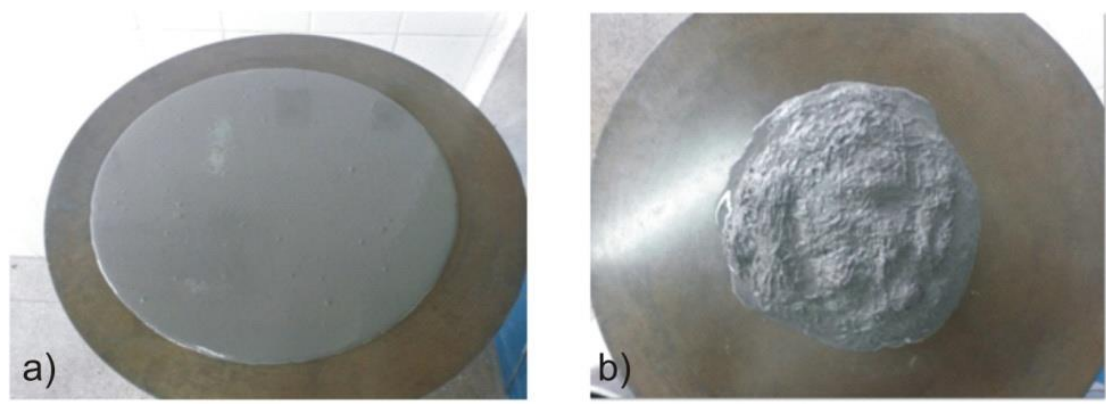

Fig. 3. Consistency measure of a: a) self-compacting matrix; b) fiber cement composite

The mixtures were produced using a mixer with a capacity of $20 \mathrm{dm}^{3}$. The following mixing procedure was used to produce the plain concrete. Cement and fly ash were homogenized in the mixer, and then the water and superplasticizer were added. Silica fume and fine aggregate were added and mixed for 4 minutes at low speed (125 RPM). After this, the mixing process was stopped during 30 seconds to remove the material retained in the mixer walls. Then, the mixing procedure continued for more 2 minutes at medium speed (220 RPM). The VMA was added and mixed for another 4 minutes at 125 RPM. To produce the FRC, the plain concrete was produced using the same procedures as described and, before the addition of VMA, chopped sisal fibers of 40 mm length $\left(\mathrm{V}_{\mathrm{f}}=6 \%\right)$ were added and mixed for more 4 minutes.

\subsection{Test methods of materials}

Water absorption tests were carried out in two cylindrical specimens of dimensions 100 $\mathrm{mm}$ in diameter and $200 \mathrm{~mm}$ in height according to ASTM C642 [32].

The compressive test, according to NBR 5739 [33], and the tensile splitting strength test, according to NBR 7222 [34], were carried out in three cylindrical specimens of 100 $\mathrm{mm}$ in diameter and $200 \mathrm{~mm}$ in height. The specimens were tested on a $2000 \mathrm{kN}$ testing 
machine at a rate of axial loading of $500 \mathrm{~N} / \mathrm{s}$. For splitting tensile tests a load cell of 50 $\mathrm{kN}$ was used.

For the flexural test, initially flat plates with dimensions of $400 \times 400 \times 10 \mathrm{~mm}^{3}$ were molded. The mortar mix was manually placed into a steel mold, followed by external vibration. After 28 days of curing in water immersion, the plates were cut in prismatic specimens with dimensions of $400 \mathrm{~mm} \times 70 \mathrm{~mm} \times 10 \mathrm{~mm}$ for the flexural tests. Bending tests were carried out under displacement control at a crosshead rate of $0.3 \mathrm{~mm} / \mathrm{min}$ in a Shimadzu UH-F $100 \mathrm{kN}$ machine with a load cell of $1 \mathrm{kN}$ capacity. Three specimens for each mix were tested under four-point bending configuration, as shown in Figure 4.

From the load-deflection curves two parameters were calculated to evaluate the reinforcing effect of the fiber: a) The post-cracking flexural strength of the composite determined from the maximum load carried out by the composite after the first crack event, where the concept of flexural stress $\left(f_{t f}\right)$ was obtained from the bending formula given by $f_{t f}=6 M / b d^{2}$ where $M$ is the maximum moment of the test specimen and $\mathrm{d}$ and $b$ are the depth and width of the specimen's cross section, respectively; and b) The toughness index FT [35], defined as the energy required to deflect the composite beam to a midpoint deflection of $L / 150$ of its free span $(L)$, which in this study corresponds to a deflection of $2 \mathrm{~mm}$.

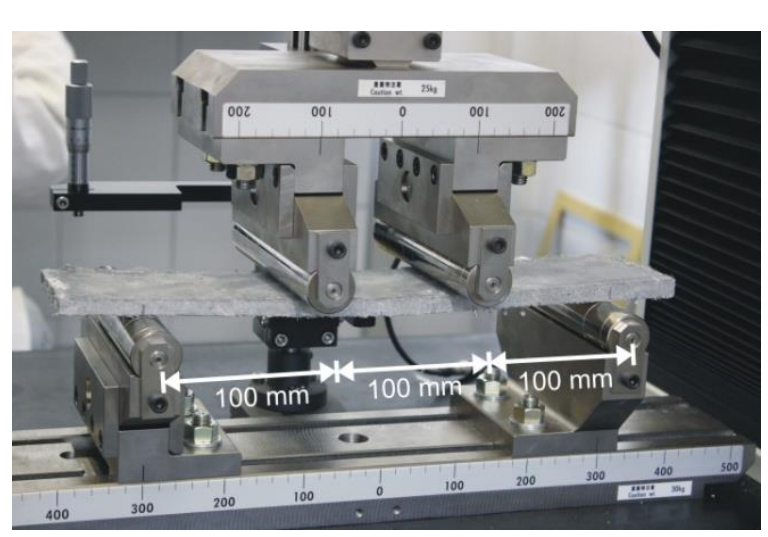

Fig. 4. The four-point bending test set-up adopted for characterizing the flexural performance of the developed materials.

Statistical evaluation was performed using the analysis of variance (ANOVA) that allows to determine whether an independent variable has, or not, an effect on the dependent variable. In addition, it can also be used to identify whether the interactions of independent variables have, or not, an effect on the dependent variable [36, 37]. In this work, ANOVA calculations were carried out according Hines al. [38] to determine 
the significance of the fiber content, recycled aggregate content and interaction between then on water absorption, compressive strength and tensile splitting strength. The properties values of three replicates at two levels of aggregate substitution ( 0 and 20\%) for two levels of fiber mass content $(0 \%$ and 6\%) are arranged in a tabular form. After that, the total sum of squares (SS) for individual factors and for the residual random error is calculated. Then the mean squares (MS) of the factors are calculated by dividing their corresponding SS by the associated degrees of freedom (DF). The effect of individual factors is evaluated by testing the hypothesis of equality of variances, which is the test of null hypothesis or simply the test of meaning at a particular probability level. For this purpose, the ratio of mean squares of factors to the mean squares of the residual error, i.e. the calculated F-values, are compared to the tabulated F-values. A reliability level of 95\% was adopted. Tukey's tests were also used to identify the significant differences $(\mathrm{P}<0.05)$ among the values of the properties of the plain concretes and those values for the fiber reinforced concretes. Statistical analyses were carried out using the software Statistica (StatSoft, Inc).

\subsection{Block: geometry and production}

The block developed in this work was produced by using the natural and recycled composites reinforced with sisal fibers described in previous sections. It was adopted a design of a trapezoidal element to ensure greater lightness and also to permit the passage of cables and pipes for water supply, sewage flow, electricity and communications in the slab without decreasing the free depth of the living space. The block has dimensions and deadweight in order to be easily and quickly installed without the necessity of formwork and heavy equipment. Figure 5 compares two conventional blocks used currently in the market with the one proposed in the present work. 


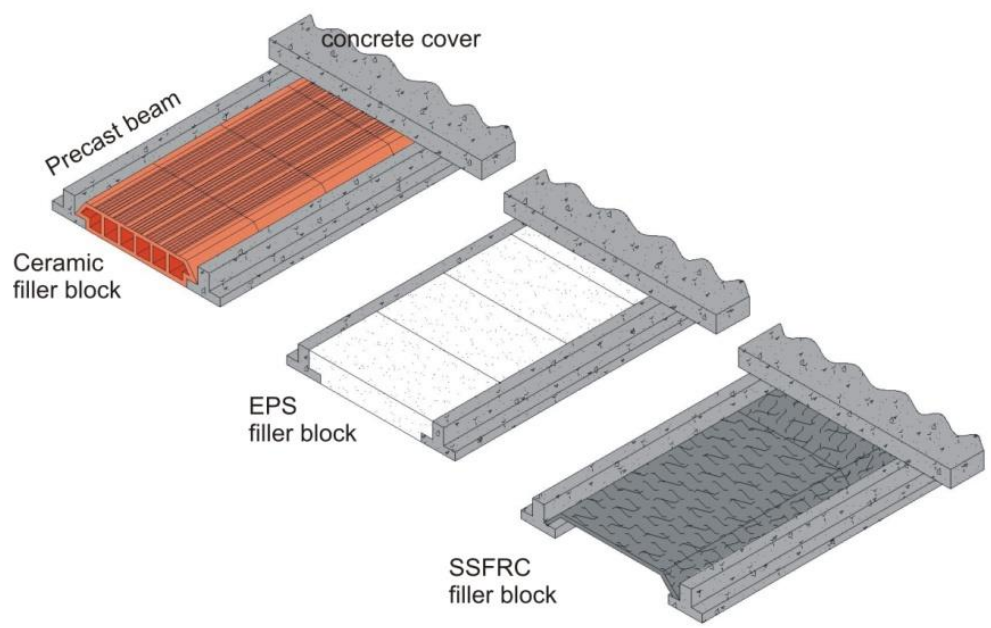

314

315

316

317

318

319

320

321

322

323

324

325

326

327

Fig. 5. Block solutions for precast one-way slab: conventional (ceramic and EPS), and the developed short sisal fiber reinforced concrete block (SSFRC)

The SSFRC blocks were produced using a metal mold with dimensions of $350 \times 50 \times 500 \times 10 \mathrm{~mm}$ (width $\times$ height $\times$ length $\times$ thickness) shown in Figure 6 . The two lateral parts of the block (herein considered the webs of the block) were firstly cast by being vibrated during $30 \mathrm{sec}$. Subsequently, the top layer (herein considered the flange component of the block) was cast by also applying a vibrating period of $30 \mathrm{sec}$.
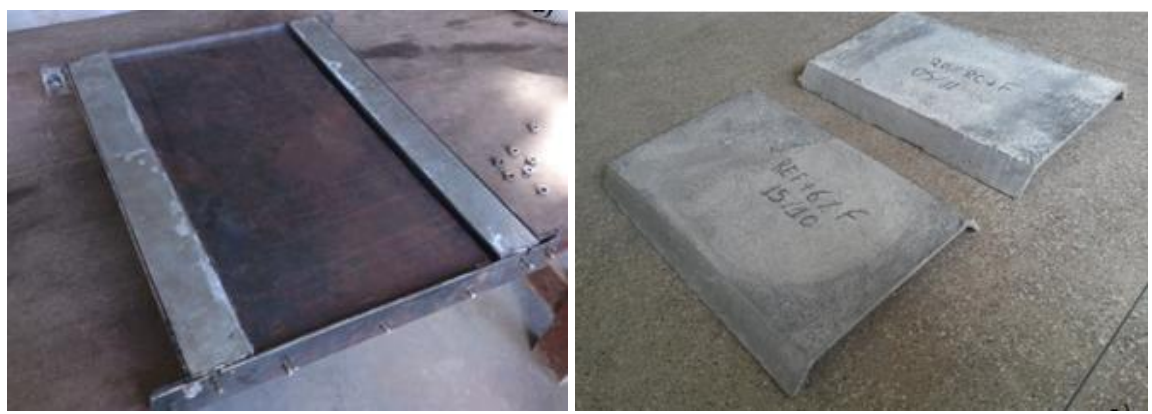

Fig. 6. Production of SSFRC block: a) metallic mold; b) blocks with natural and recycled aggregate

The blocks must have semi-structural behavior, since in spite of do not have been designed for contributing to the ultimate load carrying capacity of the slab, they must have sufficient strength to withstand several load conditions. In fact, during the execution of the slab they must safely support the weight of workers and equipment and, subsequently, must resist the weight of fresh concrete without failing or develop excessive deformation. To determine the block's strength, it was used the concentrated 
load test configuration specified by NBR 14859 [39]. According to this standard, it is necessary to simulate the support conditions provided by the slab's precast beams to the block, and the load transferred to the block by a worker positioned in the center of the block. To simulate the support conditions two L shape steel profiles were used, while the load applied to the block was materialized by a rectangular shape wooden plate of $75 \mathrm{~mm}$ width and $200 \mathrm{~mm}$ long, with a thickness of $30 \mathrm{~mm}$ (see Figure 9). The test was carried out using an electromechanical universal machine of $100 \mathrm{kN}$ capacity, with a load cell of $5 \mathrm{kN}$, under displacement control at $1 \mathrm{~mm} / \mathrm{min}$ in the center zone of the block, by using an LVDT measuring the deflection in this zone. Three samples were tested for each type of block.

\subsection{One-way slab panels}

The applicability of the new SSFRC block in a real slab was investigated by producing and testing four slab panels: one made by blocks of clay ceramics, another built with EPS blocks, and the other two with SSFRC blocks (Figure 7). For each slab's panel two commercial precast beams of $2.1 \mathrm{~m}$ length were used, with $\mathrm{T}$ inverted shape and reinforced with three CA-60 steels bars with nominal diameter of $4.2 \mathrm{~mm}$. The concrete cover layer was reinforced in longitudinal and transversal directions with steel bars (CA-60) of nominal diameter of $6.3 \mathrm{~mm}$ and spaced every $250 \mathrm{~mm}$ (Figure 7).

The slab's panels were fabricated by placing the precast beams together with the blocks and steel mesh in the wood formwork, as shown in Figures 7a and 7b. A concrete cover layer (see Figure 5) of $50 \mathrm{~mm}$ thickness was cast, so that the finished slab's panels became with a total thickness of $120 \mathrm{~mm}$. This concrete was made by a mix proportion of 1:2.13:3.73:0.5 (cement: fine aggregate: coarse aggregate: water, by weight), and presented a slump of $60 \mathrm{~mm}$. At 28 days its compressive strength was $30.6 \mathrm{MPa}$, obtained following the recommendations of NBR 5739 [33]. All slab panels were tested as simply supported slab with a span length of $2.0 \mathrm{~m}$, submitted to a two-concentrated line loads applied at the middle-third of this span, as shown in Figure 7c. These slab panels were tested in a machine with a capacity of 100 $\mathrm{kN}$, under displacement control at a rate of $1 \mathrm{~mm} / \mathrm{min}$. Displacements at mid-span were continuously measured using electrical transducers (LVDTs), together with the corresponding loads. The test was stopped at a maximum load of $16 \mathrm{kN}$ to prevent the collapse of the slabs and damage of the equipment. 

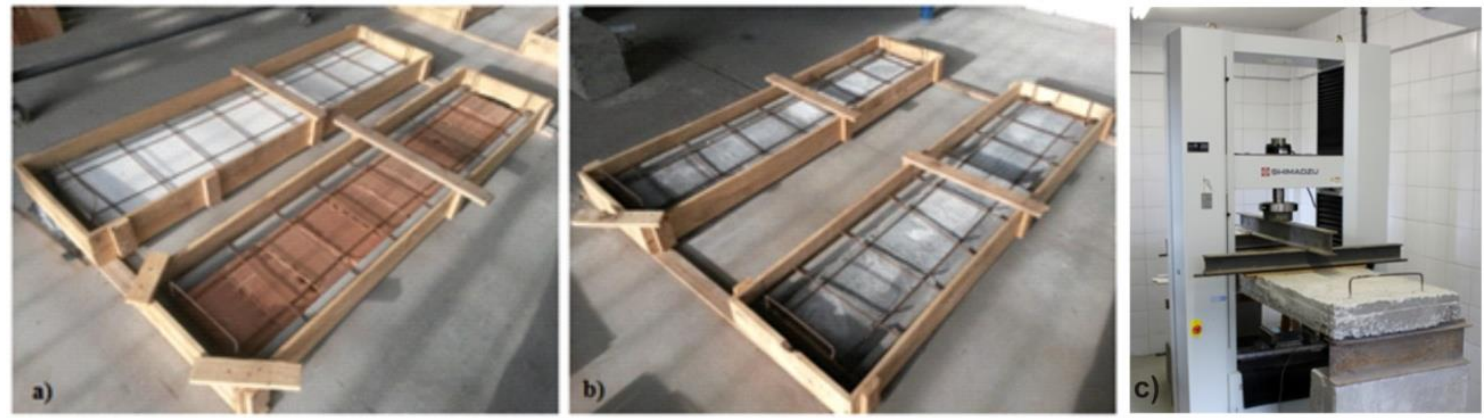

Fig. 7. Slab panels before concrete casting including: a) conventional blocks; b) SSFRC blocks; c) Slab test setup.

\section{Experimental results and discussion}

\subsection{Physical and mechanical properties}

The results of experimental analysis of PC and FRC using natural and recycled aggregates are shown in Table 4. According to the analysis of variance (ANOVA), shown in Table 5, the addition of recycled aggregate, the addition of sisal fibers and the simultaneous use of fibers and recycled aggregate had a statistically significant effect on water absorption and compressive strength. The splitting tensile strength, in turn, was significantly affected statistically only by the addition of recycled aggregate.

The results of Table 4 indicated, as expected, a gradual increment of water absorption with the incorporation of recycled aggregate and sisal fibers. It is observed that the increase of water absorption of the mixes ranged from $8 \%$ to $17 \%$, with respect to the PC, and the highest water absorption rate was obtained in the mixture (Table 3) with simultaneous use of recycled aggregate and sisal fibers. Recycled aggregate is very porous and shows a high absorption of water (see Table 1). Santos [40] verified an increase of porosity of about $9 \%$ of mortar for replacement contents of $20 \%$ of natural aggregate. Oliveira [41] verified an increase of $7 \%$ in water absorption of mortar when $25 \%$ of the natural aggregate was replaced by recycled aggregate, which was attributed to the porosity of the recycled aggregate and the increase of the water/cement ratio.

The fiber addition caused an increase of absorption of about $17 \%$ and $34 \%$ relative to the plain concrete and the plain recycled concrete, respectively. The fibers have reduced the workability of the material (see Figure 3) and a greater amount of air was incorporated during the mixing process and casting, making it more porous. However, the self-compacting matrix used in the present work permitted the incorporation of a relatively high fiber content without occurrence of fiber balling or segregation of the mixture. Thus, it was possible to achieve lower absorption and porosity values than 
obtained when using conventional matrices. According to Melo Filho [42], the increase of water absorption and porosity of composites is proportional to the fiber content and fiber length; for composites reinforced with $4 \%$ or $6 \%$ of sisal fiber an increase of up to $96 \%$ in water absorption was observed.

Table 4

Mechanical and physical properties of concretes

\begin{tabular}{lccc}
\hline Mix & $\begin{array}{c}\text { Water Absorption } \\
(\%)\end{array}$ & $\begin{array}{c}\text { Compressive } \\
\text { strength } \\
(\mathrm{MPa})\end{array}$ & $\begin{array}{c}\text { Tensile splitting } \\
\text { strength (MPa) }\end{array}$ \\
\hline PC & $4.12 \pm 1.1^{\mathrm{a}}$ & $46.50 \pm 2.1^{\mathrm{a}}$ & $3.53 \pm 0.2^{\mathrm{a}}$ \\
PRC & $4.45 \pm 0.9^{\mathrm{b}}$ & $54.67 \pm 1.0^{\mathrm{b}}$ & $2.80 \pm 0.5^{\mathrm{b}}$ \\
FRC & $4.84 \pm 0.9^{\mathrm{c}}$ & $36.27 \pm 1.8^{\mathrm{c}}$ & $3.62 \pm 0.1^{\mathrm{a}}$ \\
FRRC & $5.95 \pm 0.5^{\mathrm{d}}$ & $36.73 \pm 0.9^{\mathrm{c}}$ & $3.08 \pm 3.1^{\mathrm{b}}$ \\
\hline
\end{tabular}

Values bearing a different letter in the same column are significant at $\mathrm{P}<0.05$. All values are mean $\pm \mathrm{SD}(\mathrm{n}=3)$

401

Table 5

403

Analysis of variance (ANOVA) results

\begin{tabular}{|c|c|c|c|c|c|}
\hline Factor & $\mathrm{DF}^{*}$ & $\mathrm{MS}^{*}$ & F-values & $\mathrm{p}(95 \%)$ & Significance \\
\hline \multicolumn{6}{|c|}{ Water absorption } \\
\hline A: RA & 1 & 1.575 & 941.042 & 0.000 & Yes \\
\hline B: Fiber & 1 & 3.694 & 2206.314 & 0.000 & Yes \\
\hline Interaction $\mathrm{AB}$ & 1 & 0.455 & 272.294 & 0.000 & Yes \\
\hline Error & 8 & 0.001 & & & \\
\hline \multicolumn{6}{|c|}{ Compressive strength } \\
\hline A: RA & 1 & 55.810 & 17.839 & 0.003 & Yes \\
\hline B: Fiber & 1 & 595.310 & 190.286 & 0.000 & Yes \\
\hline Interaction $\mathrm{AB}$ & 1 & 44.600 & 14.257 & 0.000 & Yes \\
\hline Error & 8 & 3.13 & & & \\
\hline \multicolumn{6}{|c|}{ Splitting strength } \\
\hline A: RA & 1 & 1.223 & 16.056 & 0.004 & Yes \\
\hline B: Fiber & 1 & 0.099 & 1.297 & 0.288 & No \\
\hline Interaction $\mathrm{AB}$ & 1 & 0.026 & 0.346 & 0.573 & No \\
\hline Error & 8 & 0.076 & & & \\
\hline
\end{tabular}

404

${ }^{*}$ DF - Degree of freedom, MS - Mean squares

405 For the developed materials, the substitution of $20 \%$ of natural aggregate by recycled 406 aggregate has resulted in an increase of about $17 \%$ compressive strength. Similar results 407 were found by several authors. Neno et al. [43] using substitution levels of 20, 50 and $408100 \%$ of natural aggregate by recycled concrete aggregate obtained an increase in the 409 compressive strength of 36, 31 and $88 \%$, respectively. According to these authors, the 410 increase in the compressive strength with the percentage of replacement of natural by 411 recycled aggregate can be explained by the high levels of cement adopted in these 412 materials and densification of matrix due finer granulometry of recycled aggregate. 413 Corinaldesi et al. [44] justified the increase of the compressive strength with the 414 percentage of recycled aggregate to the shape of recycled aggregate particles that 
415 contributes to improve the bond strength at the interface between aggregate and 416 surrounding cement paste. For the composites, however, the addition of the recycled 417 aggregate did not statistically affect the compressive strength, as shown in Table 4. This 418 indicates that the positive contribution of the recycled aggregate could not overcome the 419 detrimental effects introduced in the matrix due to the incorporation of the fiber. The 420 use of short vegetable fibers in cement based materials usually reduces their 421 compressive strength mainly due increase in the matrix porosity. In this work the 422 addition of fibers resulted in a reduction of the compressive strength of about $22 \%$ and $42333 \%$, relative to plain concrete and plain recycled concrete, respectively. The decrease 424 of compressive strength observed in this study, however, is much lower than the one 425 pointed out in other works [45]; this behavior can be justified by the self-compacting 426 nature of the plain concrete which results in lower air content incorporated during 427 mixing and casting and, consequently, lower porosity of the fiber reinforced concrete.

428 Figure 8 shows one representative flexural stress-deflection curve for the natural 429 composite (SSFRC with natural aggregate) and recycled composite (SSFRC with 430 recycled aggregate) tested at 28 days of age; gray domain represents the envelope of 431 results of all samples. The average recorded data with their coefficient of variation $(\mathrm{CV})$ is presented in Table 6 .
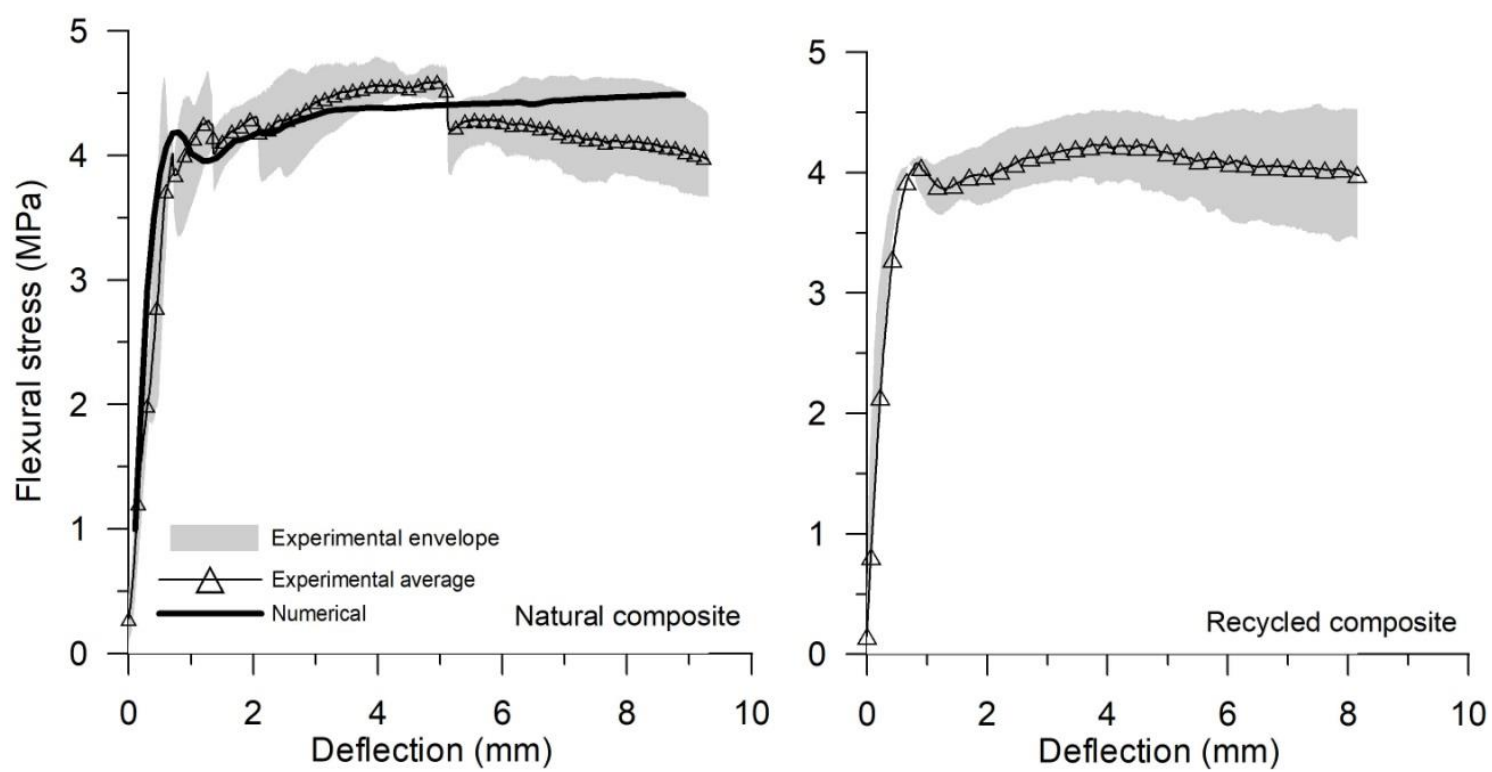

Fig. 8. Flexural stress versus midspan deflection obtained in four point bending tests (Figure 4) with 436 specimens of natural and recycled composites 
438 Usually, the addition of short vegetable fiber in cement based composite results in a material with softening behavior in bending and the development of a unique crack before the rupture of the specimen [28]. However, in the composites developed in the present work, the maximum flexural capacity was $14 \%$ higher than the flexural stress at cracking initiation. Furthermore, although short $40 \mathrm{~mm}$ length fibers have been used, several cracks were formed up to the deflection level (about $6 \mathrm{~mm}$ ) where cracking process attained its stabilized stage. Similar behavior was registered by Ferreira et al. [20], however, using a matrix with higher content of cement (cement/sand ratio of 2) and fibers of larger length $(50 \mathrm{~mm})$.

447 The statistical analysis of the average values of the strength performance of the developed materials demonstrated that the replacement of natural aggregates by recycled aggregates had not influence on the cracking and maximum flexural stress of the tested specimens. However, the toughness index FT has decreased up 13\% when recycled aggregate was used in the matrix, indicating a detrimental influence on the fiber pullout performance caused by this replacement.

Table 6

Results of four point bending tests

\begin{tabular}{cccc}
\hline Concrete & $\begin{array}{c}\text { First crack } \\
\text { strength } \\
\mathrm{MPa}\end{array}$ & $\begin{array}{c}\text { Flexural } \\
\text { strength } \\
\mathrm{MPa}\end{array}$ & $\begin{array}{c}\text { FT } \\
\mathrm{N} / \mathrm{mm}^{2}\end{array}$ \\
\hline FRC & $4.31(7.1)^{\mathrm{a}}$ & $4.72(1.8)^{\mathrm{a}}$ & $3.54(6.44)^{\mathrm{a}}$ \\
FRRC & $3.97(5.9)^{\mathrm{a}}$ & $4.63(3.5)^{\mathrm{a}}$ & $3.09(12.0)^{\mathrm{b}}$ \\
\hline \multicolumn{2}{l}{ Values bearing a different letter in the same column are significant at }
\end{tabular}
$\mathrm{P}<0.05$. Coefficient of variation into round brackets $(\mathrm{n}=3)$

\subsection{Evaluation of the structural performance of the blocks}

458 Figure 9 shows a representative load-displacement curve for each type of block 459 investigated materials: short sisal fiber reinforced concrete (SSFRC), short sisal fiber 460 reinforced recycled concrete (SSFRRC), EPS and ceramic. The photos included into 461 Figure 9 indicate the block situation at the end of the test. Table 7 shows the load when 462 the first crack was detected, cracking load $\left(\mathrm{P}_{\text {cr }}\right)$, as well as the maximum load $\left(\mathrm{P}_{\max }\right)$ and $463 \mathrm{P}_{\mathrm{cr}} / \mathrm{P}_{\max }$ ratio. 

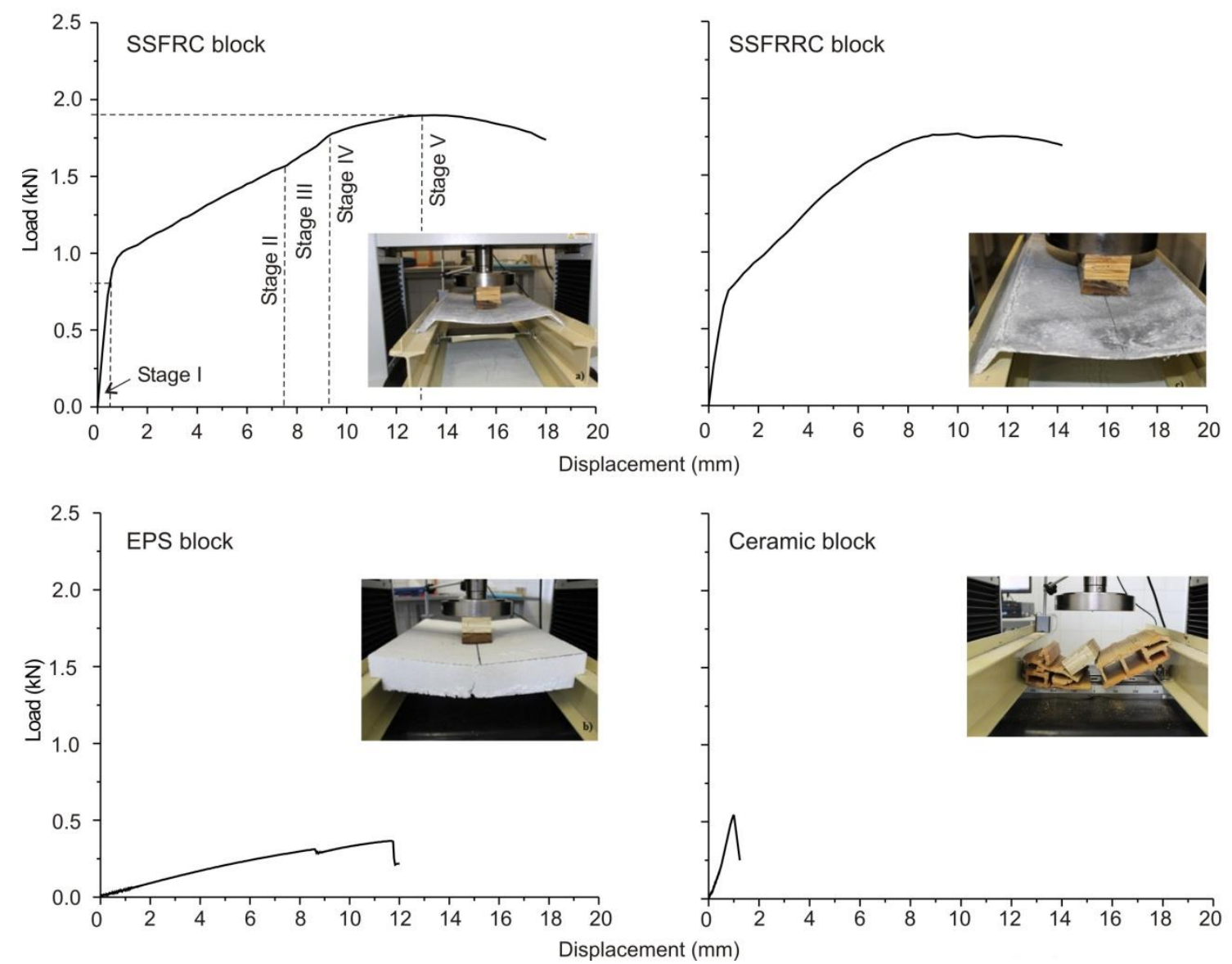

Fig. 9. Load-displacement response of filler blocks under flexion

Table 7 shows that traditional blocks have not reached the minimum load required by NBR 14859 [39], which is $0.7 \mathrm{kN}$ for blocks less than $80 \mathrm{mmm}$ in height. When compared to this load target, the maximum load supported by the ceramic and EPS blocks was, respectively, $37 \%$ and $47 \%$ smaller. These results are consistent with observations in the execution of prefabricated slabs where these types of blocks are used, with ceramic elements failing during transport and application, and EPS blocks rupturing during the application of the concrete cover layer [3]. In addition, a brittle rupture behavior was observed in Figure 9 for both blocks. The ceramic and the EPS blocks do not have strength capacity for suspending any type of the infrastructures circulating in the bottom surface of the slabs, while the proposed new FRC blocks demonstrated potentiality for this demand. The maximum load of the FRC blocks was about $157 \%$ higher than the minimum load required by the standard for the blocks for this type of slabs. 
Results of the structural tests with the investigated block

\begin{tabular}{cccc}
\hline Block's designation & $\begin{array}{c}\mathrm{P}_{\mathrm{cr}} \\
\mathrm{kN}(\mathrm{CV})\end{array}$ & $\begin{array}{c}\mathrm{P}_{\max } \\
\mathrm{kN}(\mathrm{CV})\end{array}$ & $\mathrm{P}_{\max } / \mathrm{P}_{\mathrm{cr}}$ \\
\hline Ceramic & $0.44(26.3)^{\mathrm{a}}$ & $0.44(26.3)^{\mathrm{a}}$ & 1.00 \\
EPS & $0.37(0.8)^{\mathrm{b}}$ & $0.37(0.8)^{\mathrm{b}}$ & 1.00 \\
SSFRC & $0.79(8.5)^{\mathrm{c}}$ & $1.83(23.4)^{\mathrm{c}}$ & 2.32 \\
SSFRRC & $0.79(14.3)^{\mathrm{c}}$ & $1.76(19.6)^{\mathrm{c}}$ & 2.23 \\
\hline
\end{tabular}

Values bearing a different letter in the same column are significant at $\mathrm{P}<0.05$. Coefficient of variation into round brackets $(\mathrm{n}=3)$

From the load-deflection curve of the SSFRC and SSFRRC blocks, it can be seen they present a deflection hardening response. The initial linear response ends at a cracking load (stage I) that was similar in both blocks $(\cong 0.8 \mathrm{kN})$. The post cracking phase was characterized by a multiple cracking formation in the bottom surface of block (stage II) until no more cracks can form (cracking formation stage) and the crack spacing becomes constant. The widening of the existing cracks takes place in stage III. After this, in stage IV, the inelastic behavior of fiber reinforced material sections leads to a redistribution of moments and forces, resulting in an increase of load carrying capacity. With the increase of load, pseudo-hinges start being formed in succession at locations where the maximum moment capacity was reached; during this loading process, these pseudo-hinges have continuously rotate until the last pseudo-hinge has formed (webflange connection zones), converting the structure into a mechanism, which corresponds to the end of stage IV. In the structural softening phase (stage V) the pseudo-hinges corresponding to the mechanism rotate by widening and localizing the macro-cracks in the zones of maximum bending moments (stage V). The effect of partial replacement of natural by recycled aggregate on the maximum load capacity of SSFRC blocks was evaluated by comparison test Tukey's, as shown in Table 7. It was found that the recycled aggregate caused no statistically significant changes in the maximum load of the blocks as well as had not affected the first crack strength of the concrete, as shown in Table 6.

507 The $\mathrm{P}_{\max } / \mathrm{P}_{\text {cr }}$ ratio (shown in Table 7) was about 2.2 and 2.3 for SSFRC block with natural and recycled aggregate, respectively. Comparing this residual strength ratio with the specification suggested by Bank et al. [46] for permanent formwork system, both the FRC blocks, regardless of have been made with natural or recycled aggregates, can be classified as the upper class (A-3 class), which indicates that the formwork blocks are intended to be cracked for the design service loads. The maximum load is reached at a relatively large deformation, which indicates the large ductility and energy absorption 
514 capacity of the SSFRC. This quite large deformability was attained with the SSFRC

515 blocks maintaining their integrity, which is quite favorable in terms of the safety of the 516 workers during the execution of the slab.

\section{$517 \quad 3.3$ Structural response of the slabs}

518 The structural behavior of the slabs was analyzed through the load versus displacement curves (Figure 10) and cracking pattern (Figures 11 and 12).

520

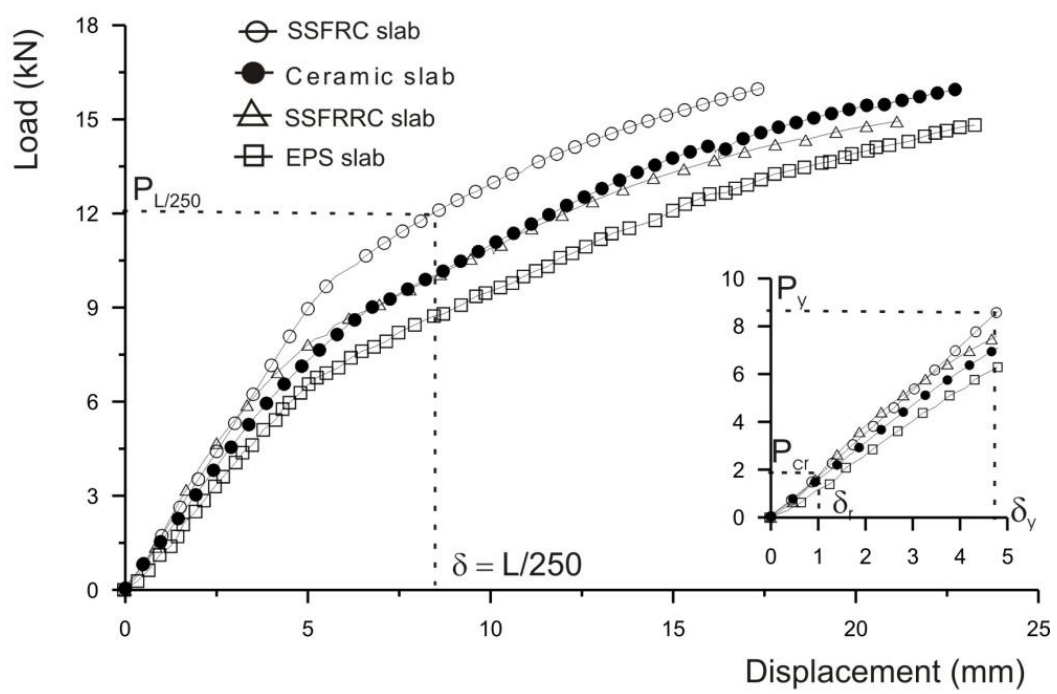

521

522

523

524

525

526

527

528

529 530

531

532

Fig. 10. Load vs. midspan displacement of slab panels

The first stage of linear response in the tested slabs is of very small amplitude due to the relatively low area of concrete in tension and tensile strength of the concrete of the prefabricated RC beams. This tendency was already observed by other authors [10, 11]. Cracking load $\left(\mathrm{P}_{\mathrm{cr}}\right)$ has occurred at a load interval between 1.8 and $2.0 \mathrm{kN}$ (Table 8). This table 8 also includes the load at steel yield initiation $\left(\mathrm{P}_{\mathrm{y}}\right)$, and at serviceability limit deflection state conditions $\left(\mathrm{P}_{\mathrm{L} / 250}\right)$, i.e., at a deflection limit $\delta_{\text {limit }}=\mathrm{span} / 250=8.4 \mathrm{~mm}$.

Table 8

Results of slab bending test

\begin{tabular}{lccc}
\hline Type of filler block & \multicolumn{3}{c}{ Load $(\mathrm{kN})$} \\
\cline { 2 - 4 } & $\mathrm{P}_{\text {cr }}$ & $\mathrm{P}_{\mathrm{y}}$ & $\mathrm{P}_{\mathrm{L} / 250}$ \\
\hline Ceramic & & 6.49 & 10.17 \\
EPS & 1.8 to 2.0 & 5.97 & 9.10 \\
SSFRC & 8.93 & 12.50 \\
SSFRRC & & 7.33 & 10.12 \\
\hline
\end{tabular}


534 After cracking load and up to the yield initiation of the flexural reinforcement of the

535

536

537

538

539

540

541

542

543

544

545

546

547

548

549

550

551

552

553

554

555

556

557

558

559

560

561

562 pre-fabricated beams, the slabs with SSFRC blocks presented higher stiffness than slabs with the other two types of blocks (Figure 10), which can be justified by the cracking process shown in Figure 11. In fact, the continuity of the cracks in the pre-fabricated beams and SSFRC blocks, clearly visible in Figure 11b, demonstrates the contribution of these blocks for the flexural capacity of the corresponding slabs, as is visible in Figure 10. The cracking continuity in pre-fabricated beams and SSFRC blocks also indicates good bond conditions between these blocks and concrete cover layer. Therefore, in spite the main aim of the proposed SSFRC blocks is to demonstrate the possibility of producing cost competitive blocks of larger in plane dimensions for quicker execution of this type of slabs, of higher load carrying capacity and suitable geometry for suspending and hiding infrastructures like pipelines of building functionalities, and to constitute elements of much higher ductility and material integrity due to safe reasons for the operators, the structural response of the tested slabs demonstrates these SSFRC blocks can be optimized for providing non negligible contribution for the load carrying capacity of this type of slabs.
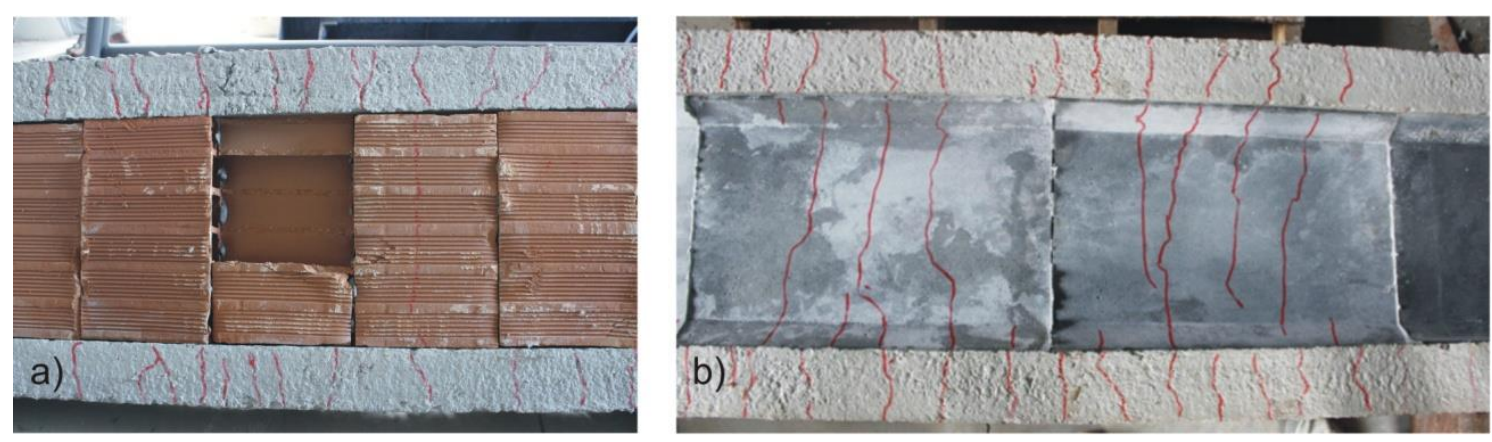

Fig. 11. Crack pattern: a) ceramic slab; b) SSFRC slab

The higher load carrying capacity at yield initiation and at post yielding stage of the FRC slab is justified by the larger load carrying capacity of the corresponding SSFRC blocks (formed with natural aggregate), Figure 9. This supports the relevance, aforementioned indicated, of this type of blocks for the load carrying capacity of this type of slabs. After yield initiation the stiffness of the tested slabs has decreased but was still appreciable due to the contribution of the top flexural reinforcement of the prefabricated beams and the concrete cover layer that have enter in tension with the progressive propagation of the flexural cracks towards the top surface of the slab (Figure 12). 
564

565

566

567

568

569

570

571

572

573

574

575

576

577

578

579

580

581

582

583

584

585

586

587

588

589

590
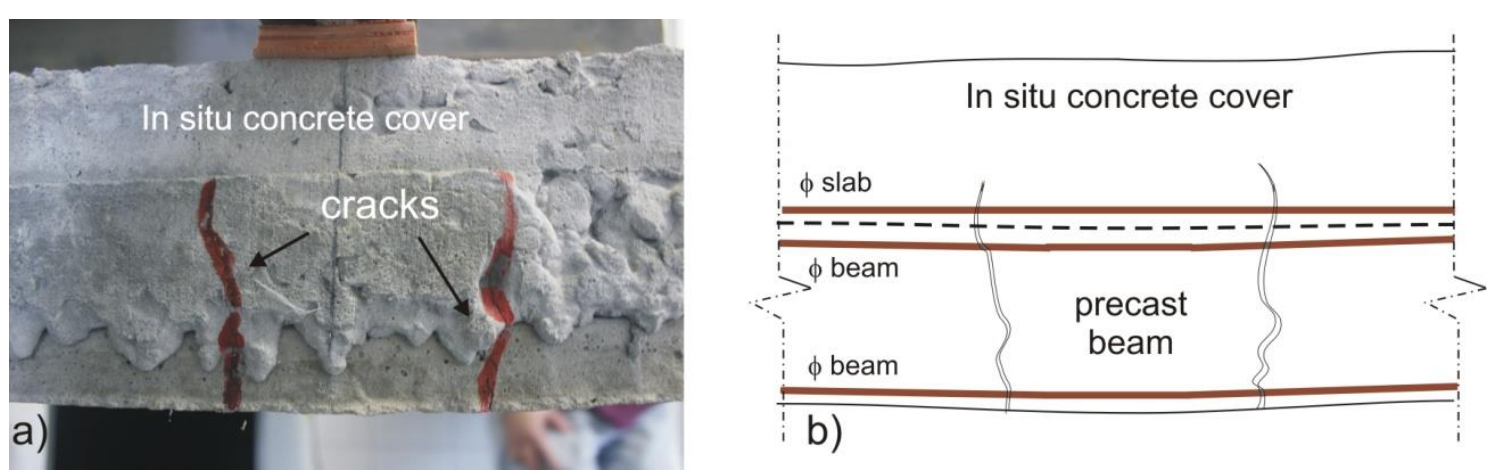

Fig. 12. Cracking propagation: a) experimental identification; b) cracks crossing steel reinforcement bars $(\phi)$ of precast beam and concrete cover layer

\section{NUMERICAL MODELLING}

\subsection{Introduction}

Previous section has demonstrated that the SSFRC block contributes for the stiffness of the deflection response of the slab. Therefore, this sections aims to assess the influence of relevant geometric aspects of the SSFRC block on its load carrying capacity. To perform reliable analysis, a model capable of simulating the relevant nonlinear phenomena, like crack formation and propagation, should be used, which requires the determination of the fracture mode I parameters of the SSFRC material, since the SSFRC block has failed in bending.

\subsection{Evaluation of the fracture mode I parameters of SSFRC}

The fracture mode I parameters were obtained by performing inverse analysis (IA) according to the strategy described in Lima et al. [22], considering the results registered in the four point bending tests described in Section 2.2, whose results are presented in Section 3.1 (Figure 8). In the simulations of the IA, and of the FRC block, the specimens were modeled with a 3D Reissner-Mindlin layered shell theory, while the material nonlinear behavior due to cracking was simulated with a multidirectional fixed smeared crack model (MDFSCM) available in the FEMIX computer program. The layered shell theory and the MDFSCM are described in detail elsewhere [47]. A smeared approach was selected because in the experimental tests carried out with bending specimens and FRC blocks several cracks were formed in the most tensioned zones. In recent study [48] the numerical approach based on the 'smeared crack' material model has been used successfully to model sisal concrete elements. By fitting as much as possible the obtained experimental results (Figure 8), the fracture mode I 
591 parameters indicated in Table 9 were determined, where the meaning of the symbols are shown in Figure 13.

593

Table 9

Values of the parameters of the constitutive model used in the numerical simulations (obtained from inverse analysis)

\begin{tabular}{ll}
\hline \multicolumn{1}{c}{ Property } & Value \\
\hline Poisson's ratio & $v=0.15$ \\
Initial Young's modulus & $E=12000.0 \mathrm{~N} / \mathrm{mm}^{2}$ \\
& $f_{c t}=1.1 \mathrm{MPa} ; G_{f}^{I}=1.0 \mathrm{~N} / \mathrm{mm} ; \xi_{1}=0.005 ; \alpha_{1}=0.60 ;$ \\
Trilinear tension-softening diagram & $\xi_{2}=0.50 ; \alpha_{2}=1.00$ \\
& $\tau_{t, p}^{c r}=0.5 \mathrm{~N} / \mathrm{mm}^{2} ; G_{f, s}=0.30 \mathrm{~N} / \mathrm{mm} ; \beta=0.1$ \\
Parameters modeling the in-plane-shear & $G_{f}^{I I I}=1.0 \mathrm{~N} / \mathrm{mm}^{\prime}$ \\
Parameters modeling the out-plane-shear & $p_{2}=2$ \\
Parameter defining the mode I fracture energy & \\
available for the new crack (Sena-Cruz 2004) & $l_{b}=$ Square root of the area of the integration point \\
[49] & $\alpha_{t h}=30^{\circ}$ \\
Crack bandwidth & 2 \\
Threshold angle & \\
Maximum number of cracks per integration & \\
point &
\end{tabular}

597

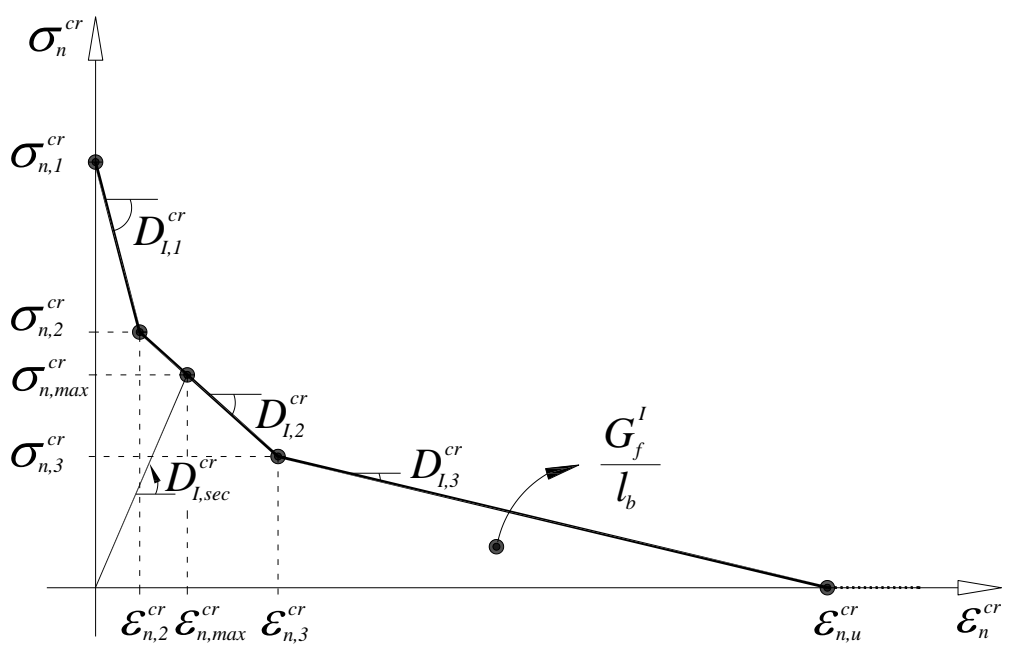

601

602 These values demonstrate that an abrupt load decay occurred just after the crack 603 initiation due to the incapacity of fibers to support the energy release in the fracture of 604 the matrix $\left(\xi_{1}=0.005, \alpha_{1}=0.60\right)$. This stage was followed by a pseudo-hardening 
phase $\left(\xi_{2}=0.50, \alpha_{2}=1.00\right)$, due to the contribution of fiber reinforcement mechanisms.

\section{$607 \quad 4.2$ Numerical modelling of the SSFRC block}

608 Due to the double symmetry of the testing conditions of the SSFRC block (see Figure 609 9), only one quarter of the block was simulated numerically. For this purpose, the 3D 610 Reissner-Mindlin shell layered approach, together with a multidirectional fixed smeared 611 crack model (MDFSCM), described in Ventura et al. [47] was adopted, considering the 612 model parameters indicated in Table 9. The adopted finite element mesh is shown in 613 Figure 14 (Serendipity 8-node) together the vertical displacement field at load level 1.5 $614 \mathrm{kN}$ (which corresponding to a central deflection in the block of $7.5 \mathrm{~mm}$ ). All the 615 components of this folder type shell structure were discretized in the depth with 10 616 layers of equal thickness. For the evaluation of the stiffness matrix and internal forces a $6172 \times 2$ Gauss-Legendre integration scheme was adopted. The load $v s$ mid span deflection 618 for the FRC block registered experimentally is compared to the one obtained 619 numerically in Figure 14. It is verified that using the fracture mode I parameters 620 obtained by inverse analysis with experimental results registered in small specimens of 621 the material used in the SSFRC block, it was capable of predicting with good accuracy 622 the deformational behavior of the experimentally tested block.

623 The cracking patterns determined numerically and observed experimentally, at 624 maximum load determined numerically and registered experimentally, are compared in 625 Figure 15 The model is capable of capturing the occurrence of two critical flexural 626 cracking zones, one in the connection between the central and the inclined extremity 627 parts (due to negative bending moments on top surface), and the other in the middle 628 span of the central part (due to positive bending moments on bottom surface). 


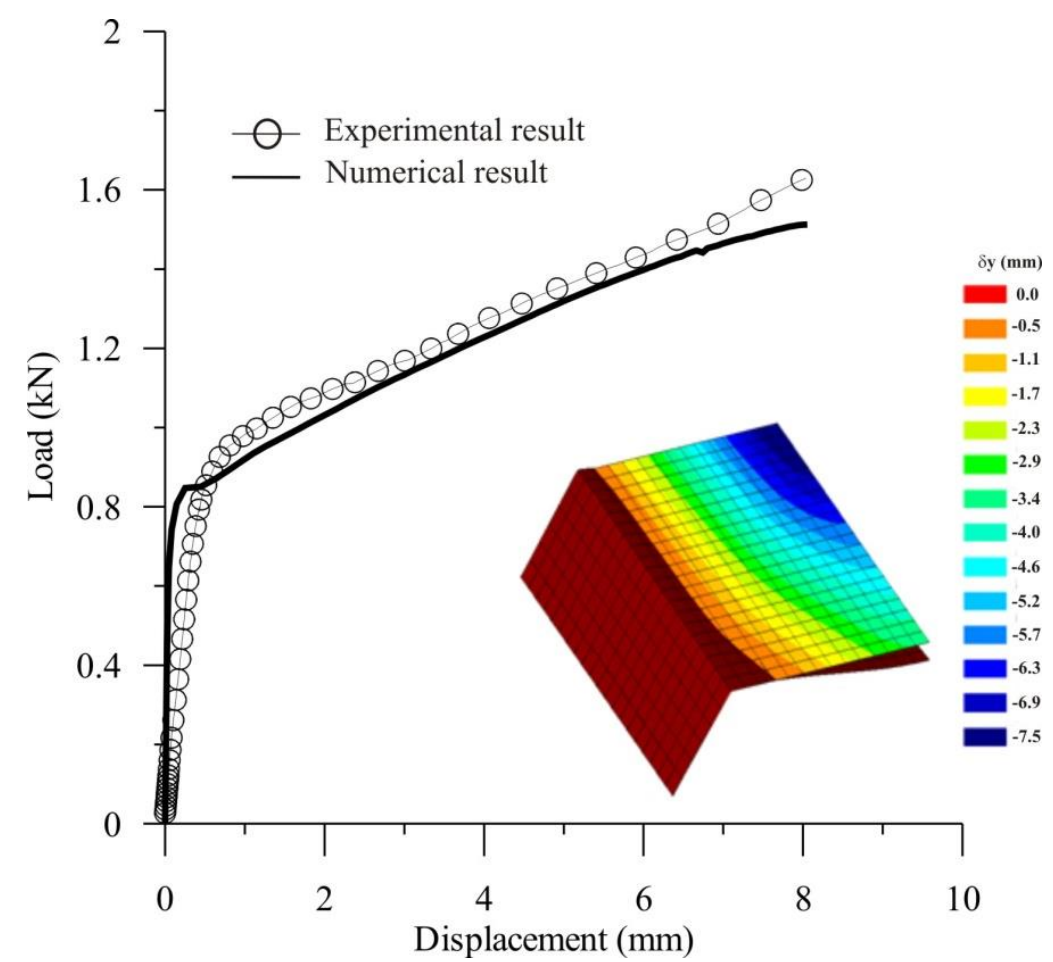

Fig. 14. Comparison of the force-deflection relationships registered experimentally and obtained 632 numerically.

633
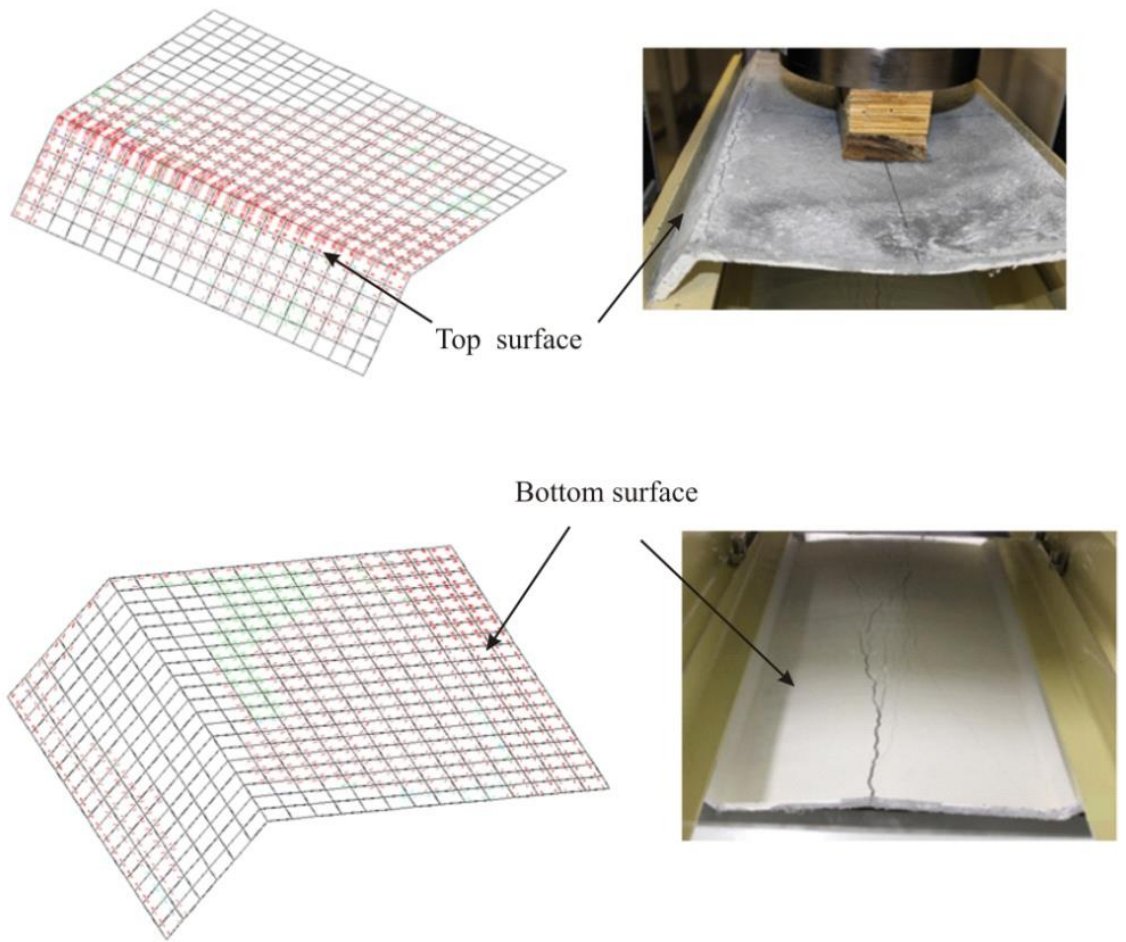

Fig. 15. Cracking pattern at maximum load determined numerically and registered experimentally: a) Top surface; b) Bottom surface. 
641 By using the finite element type and model parameters adopted in the simulations of the 642 previous section, parametric studies were carried out in order to assess the influence of 643 the wall's thickness (e) and the depth of the SSFRC block $(h)$ on its load carrying 644 capacity. For $e$ parameter it was considered 10, 12 and $15 \mathrm{~mm}$, while for $h$ it was 645 explored 100, 150, 200 and $250 \mathrm{~mm}$. By increasing the $h$, the flexural stiffness of the 646 slab also increases, as well as the possibility of passing pipes of higher dimensions or 647 other infrastructures without decreasing the effective depth of the compartment, which 648 increases the competitiveness of this solution in comparison to the ones existing 649 actually in the market. Were adopted fixed values to the width and length of block, 700 $650 \mathrm{~mm}$ and $1000 \mathrm{~mm}$, respectively, considering the maximum weight of block about $10 \mathrm{~kg}$, 651 so that it can be handled without the need for equipment.

652 The parametric studies were executed for the following two loading scenarios: 1) central 653 load, like the one adopted in the experimental tests; 2) load uniformly distributed in the 654 central part in order to simulate the deadweight of the concrete cover layer applied in 655 this type of prefabricated slabs. The results in terms of load vs. central deflection of the 656 block for these two loading scenarios are represented in Figures 16 and 17, respectively. 657 In Figure 16 an increase of the maximum load supported by the block is verified with 658 the increase of the thickness of the wall. However, as shown in Figure 18, the blocks 659 with a thickness of $10 \mathrm{~mm}$ cannot reach the minimum load of $70 \mathrm{kgf}$ required by the 660 Brazilian standard, when considering the limit state of deflection equal to L/250. 661 Increasing the width of the block generates increase in bending stresses and 662 consequently reduction in the block strength, but blocks with a thickness of 12 or 15 663 mm can be used safely. 

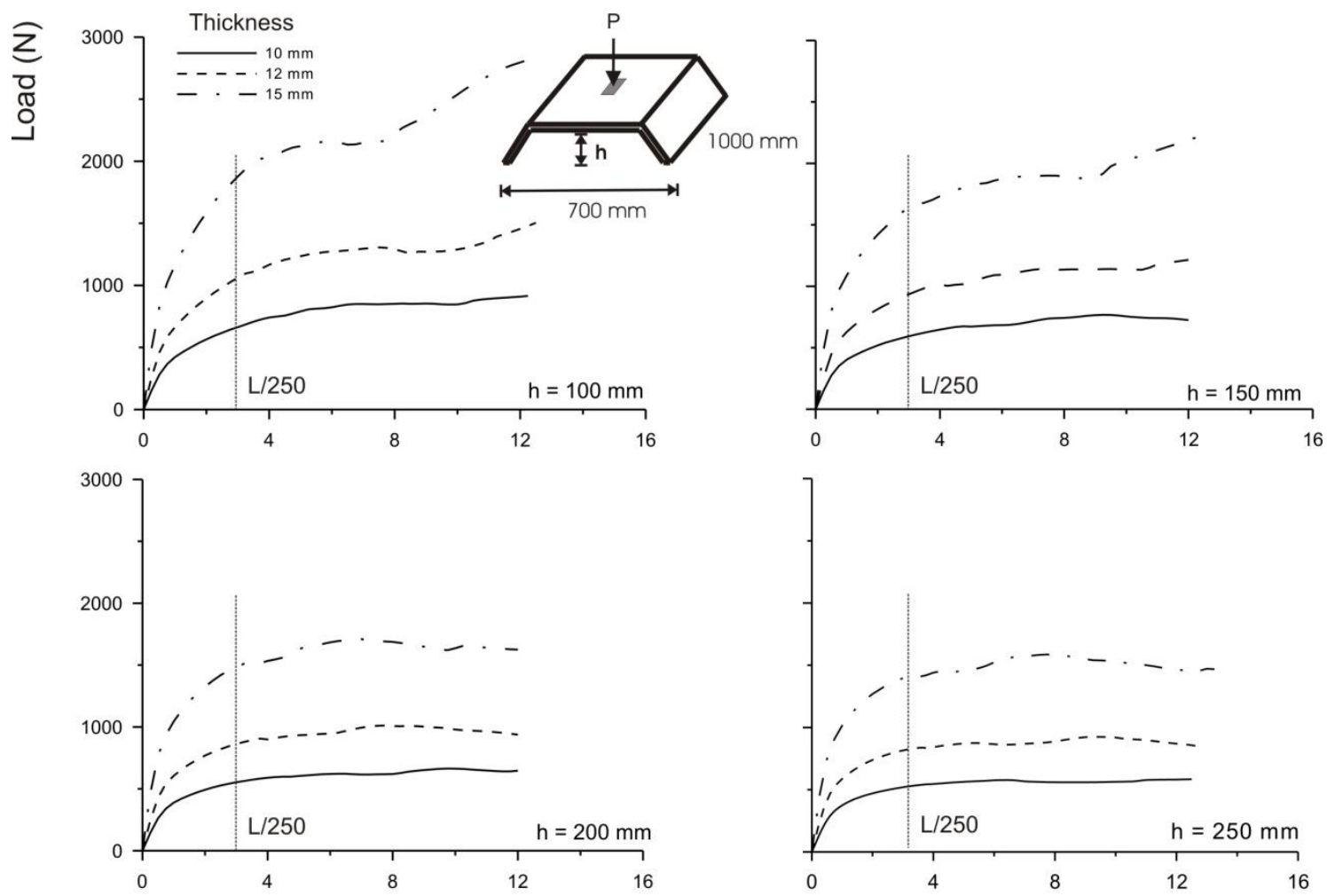

Displacement $(\mathrm{mm})$

665 Fig. 16. Effect of wall's thickness $(e)$ and depth $(h)$ of the SSFRC block on the load carrying capacity and 666 deformation performance of SSFRC block for central loading conditions 

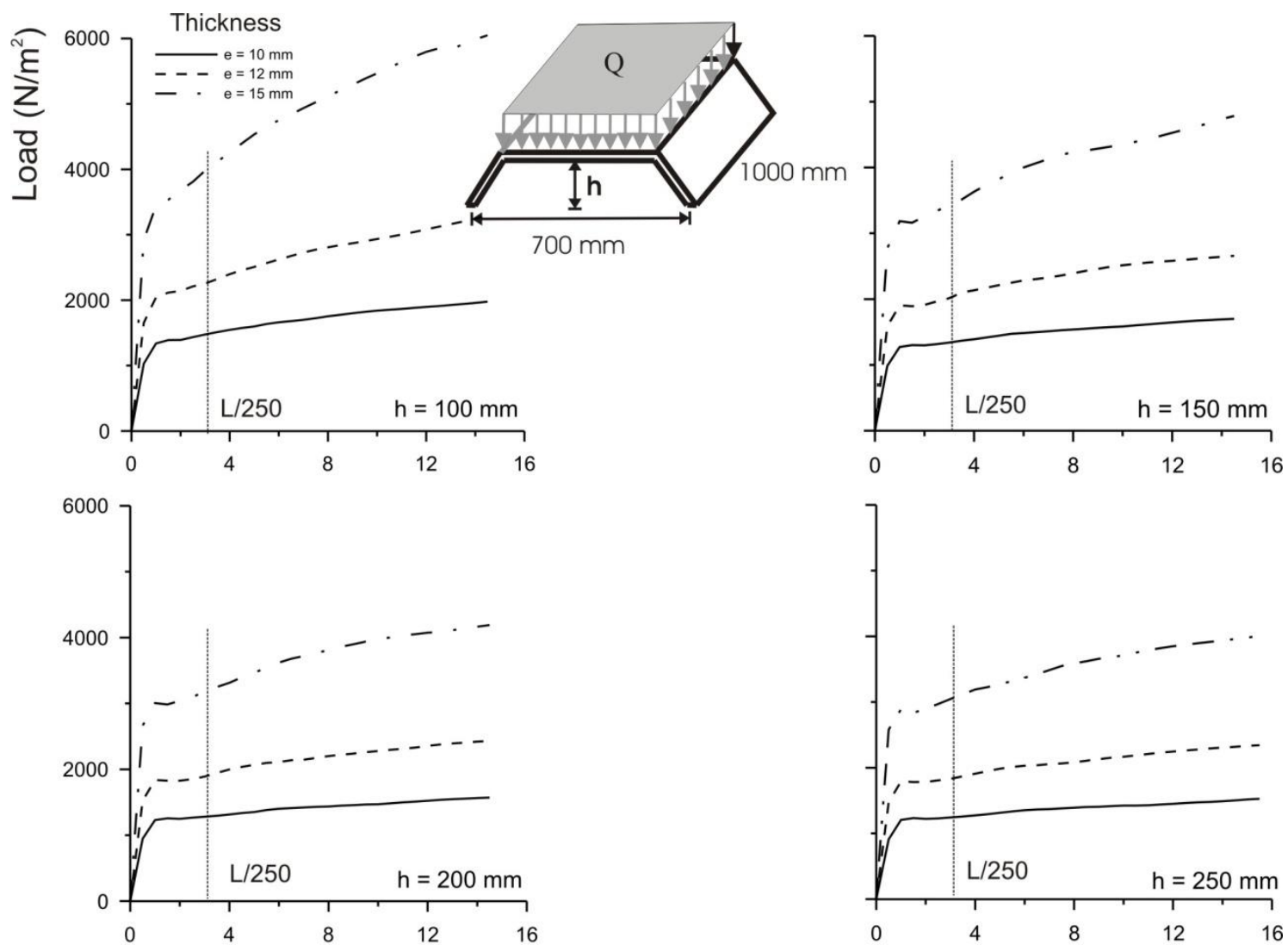

668

669

670

671

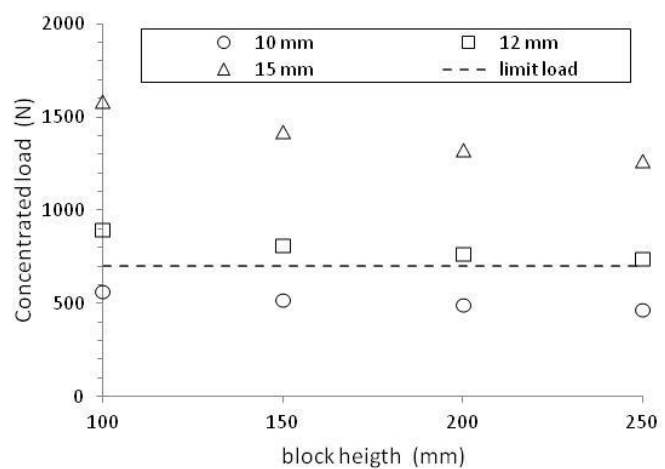

672

673

674

675

676

677

678

Displacement $(\mathrm{mm})$

Fig. 17. Effect of wall's thickness $(e)$ and depth $(h)$ of the SSFRC block on its load carrying capacity and deformation performance for uniformly distributed load in the central part of the block. 


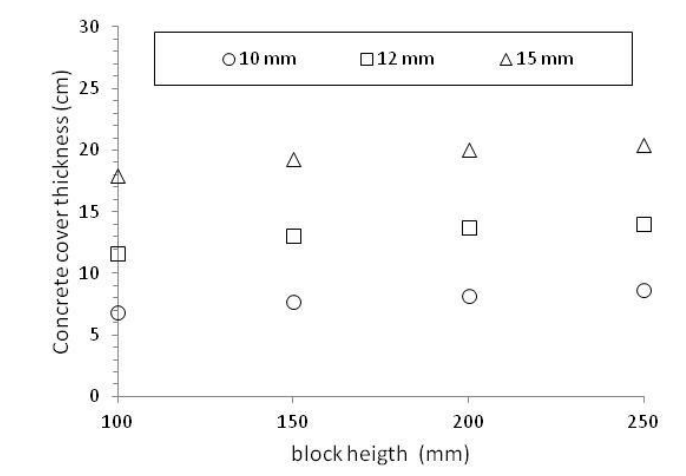

684 block.

\section{5 - Conclusions} and compressive strength.

of the block studied, it is verified that the slabs can support the weight of a layer of concrete up to $20 \mathrm{~cm}$, as shown in Figure 19, without excessive rupture or deformation of block. In this way, various configurations of slabs could be utilized with the SSFRC

Fig. 19. Maximum concrete cover thickness on the SSFRC block

In this work the potentialities of short sisal fiber reinforced recycled concrete (SSFRC) blocks were assessed by executing an experimental program and numerical modeling. The experimental evaluation of material demonstrated that the replacement of natural aggregates by recycled aggregates had not influence on the cracking and maximum flexural stress of the fiber reinforced concrete, besides the increase of water absorption

Flexural behavior of SSFRC blocks presented a typical response characterized by five phases: (I) linear-elastic; (II) multiple cracking formation in the bottom surface of block; (III) widening of the existing cracks; (IV) redistribution of moments and forces, resulting in an increase of load carrying capacity; (v) structural softening. A flexural load at crack initiation between $0.8 \mathrm{kN}$ and a maximum flexural load of about $1.8 \mathrm{kN}$ were obtained for SSFRC blocks, while the commercial blocks reached a maximum load of about $0.4 \mathrm{kN}$. These performance indicators evidence the potentialities of these composites for constituting the structural slab. In fact, the experimental evaluation of slabs panels indicated a better flexural performance when the SSFRC blocks were used, when compared to slabs using ceramic or EPS blocks. Regarding the durability of the blocks, in addition to the use of a durable matrix, it is believed that the protection offered by the slab will prevent the contact of the block with aggressive environments 
which will provide an adequate useful life. It is important to note that, as it acts as a permanent formwork, the block will only have a structural function during the placing of concrete of the slab.

Material nonlinear analysis, which describes the strain-softening behavior of concrete by a smeared crack model, was used to model the experimental behavior of the SSFRC blocks under flexion. It was possible to simulate adequately the load-displacement response of the blocks and to identify the development of the crack pattern until the rupture. This numerical model was used to simulated the news design of SSFRC block and their structural response under concentrated or distributed load. By increasing the wall's thickness and depth of the SSFRC block it is verified an increase of its load carrying capacity as well as the possibility of passing pipes of higher dimensions or other infrastructures which increases the competitiveness of this solution in comparison to the ceramic and EPS blocks.

\section{6 - Acknowledgements}

The present study is part of the activities carried out by the Authors within the PVE Program (Project 047/2012) funded by the Brazilian agency CAPES. The first author acknowledges the support of the CAPES (EST-SENIOR BEX 2579/2015-04) and CNPq. The thirst author like to thank to FAPESB.

\section{References}

[1] J.A.O. Barros, L. Ferrara, E. Martinelli, Rrecent advances on green concrete for structural purposes, Springer book, ISBN:978-3-319-56795-2, 2017.

[2] N. Anwar, G. Sthapit, Solution and systems for social and affordable housing. Asian Institute of Technology. Available at: < http://solutions.ait.asia/resources >. accessed on: march 03, 2016.

[3] J.R. Figueiredo Filho, A.K.H. Shiramizu, Manufacture and construction of buildings with precast lattice-reinforced concrete slabs. Rev. IBRACON Estrut. Mater. 4(1) (2011) 123-146.

[4] B. Lopez-Mesa, A. Pitarch, A. Tomas, T. Gallego, Comparison of environmental impacts of building structures with in situ cast floors and with precast concrete floors. Building and environment, 44(4) (2009) 699-712.

[5] EN (European Standard Norme) EN 15037-1 precast concrete products - beam-andblock floor systems - part 1: beams, 2008.

[6] P. Hájek, C. Fiala, Savings in primary material use through optimized rc or frc structures in building construction. in: sb07hk - sustainable building conference, 2007. 
proceedings...Hong Kong, p. 1-7, 2007. available in < http://www.ctislav.wz.cz/publ/2007_13_sb07hk_ph_cf.pdf>, accessed may 28, 201628.

[7] A.B. Roque, Elemento construtivo de fibrocimento contendo resíduo de concreto e 743 fibra de sisal para uso como enchimento em lajes premoldadas. (M. Sc. Thesis) 744 Programa de pós graduação em engenharia civil e ambiental/UEFS, 2015.

745

[8] J. Avilla Junior, Contribuição ao projeto e execução de lajes lisas nervuradas préfabricadas com vigotas treliçadas. (M.Sc. Thesis). Programa de Pós-graduação em Construção Civil. UFSC, 2009.

[9] I. Miličević, D. Bjegović, R. Siddique, Experimental research of concrete floor blocks with crushed bricks and tiles aggregate. Constr. Build. Mater. 94(2015) 775-783.

[10] A. Vargas, B.V. Silva, M.R. Rocha, F. Pelisser, Precast slabs using recyclable packaging as flooring support elements. J Clean Prod, 66 (2014) 92-100.

[11] Y. Yardim, A.M.T. Waleed, M.S. Jaafar, S. Laseima, AAC-concrete light weight precast composite floor slab. Constr. Build. Mater. 40(2013) 405-410.

[12] W.A. Thanoon,Y. Yardim, M.S. Jaafar, J. Noorzaei, Structural behaviour of ferrocement-brick composite floor slab panel. Constr. Build. Mater. 24(11) (2010) 2224-2230.

[13] P. Hájek, C. Fiala, A. Lupisek, Environmental design and assessment of alternatives of rc floor structures. Sustainable Building 2007, p. 317, 2007.

[14] N. Banthia, V. Bindiganavile, J. Jones, J. Novak, Fiber-reinforced concrete in precast concrete applications: research leads to innovative products. PCI Journal, 57(3) (2012).

[15] C. Yu, C. K. Y. Leung, Q. Cao, Behavior of concrete members constructed with shcc/gfrp permanent formwork. in. 7th international conference on fracture mechanics of concrete and concrete structures, 2010. proceedings...Jeju Island, korea, 2010.

[16] H.G. Schafer, G.W. Brunssen, Sisal-fiber reinforced lost formwork for floor slabs. in. vegetable plants and their fibers as building materials. proceedings of the second international symposium, 1990. proceedings...vol. 7. Routledge, p. 162-174,1990

[17] J.A. Melo Filho, F.A. Silva, R.D. Toledo Filho, Degradation kinetics and aging mechanisms on sisal fiber cement composite systems. Cem. Concr. Compos. 40 (2013) 30-39.

[18] K.J. Nagahama, A.S.M. Gadéa, P.R.L. Lima, Finite strip modeling of cementitious laminates reinforced with sisal fibers, Cem. Concr. Compos. 63 (2015) 8-16.

[19] H.E. Gram, Durability of natural fibers in concrete. Swedish Cement and Concrete Research Institute, Research no. 1:83, 1983, 225 p.

[20] S.R. Ferreira, P.R.L. Lima, F.A. Silva, R.D. Toledo Filho, Effect of sisal fiber hornification on the fiber-matrix bonding characteristics and bending behavior of cement based composites. Key Eng. Mater. 600 (2014) 421-432. 
[21] P.R.L. Lima, D.O. Santos, C.M.A. Fontes, J.A.O. Barros, R.D. Toledo Filho, Deflection hardening of sustainable fiber-cement composites. Green Materials, 4(1) (2016) 18-30.

[22] P.R.L. Lima, J.A.O. Barros, D.O. Santos, C.M.A. Fontes, J.M.F. Lima, R.D. Toledo Filho, Experimental and numerical analysis of short sisal fiber-cement composites produced with recycled matrix, European Journal of Environmental and Civil Engineering, (2016) 1-15.

[23] L.K. Aggarwal, J. Singh, Effect of plant fibre extractives on properties of cement, Cem. Concr. Compos 12(2) (1990) 103-108.

[24] S.R. Ferreira, F.A. Silva, P.R.L. Lima, R.D. Toledo Filho, Effect of fiber treatments on the sisal fiber properties and fiber-matrix bond in cement based systems, Constr. Build. Mater. 101 (2015) 730-740.

[25] R.J. Santos, P.R.L. Lima, Effect of treatment of sisal fiber on morphology, mechanical properties and fiber-cement bond strength, Key Eng. Mater. 634 (2015) 410-420.

[26] P.R.L. Lima, R.D. Toledo Filho, O.F.M. Gomes, Influence of recycled aggregate on the rheological behavior of cement mortar. Key Eng. Mater. 600 (2014) 297-307.

[27] V. Corinaldesi, G. Moriconi, Behaviour of cementitious mortars containing different kinds of recycled aggregate, Constr. Build. Mater. 23(1) (2009) 289-294.

[28] R.D. Toledo Filho, K. Ghavami, G.L. England, K. Scrivener, Development of vegetable fiber-mortar composites of improved durability. Cem. Concr. Compos. 25(2) (2003) 185-196.

[29] B.J. Mohr, J.J. Biernacki, K.E. Kurtis, Supplementary cementitious materials for mitigating degradation of kraft pulp fiber-cement composites. Cemen Cem. Concr. Res. 37(11) (2007) 1531-1543.

[30] ASTM (American Society for Testing and Materials), ASTM C618/17a Standard specification for coal fly ash and raw or calcined natural pozzolan for use in concrete, 2017.

[31] ASTM (American Society for Testing and Materials), ASTM C230 / C230m 14 standard specification for flow table for use in tests of hydraulic cement, 2003.

[32] ASTM (American Society for Testing and Materials), C642 - standard test method for density, absorption, and voids in hardened concrete, 2006, doi: 10.1520/c0642-06, www.astm.org

[33] ABNT (Brazilian Association of Technical Standards), NBR 5739: concrete compression test of cylindric specimens - method of test. Rio de Janeiro, 2007. 9p. (in portuguese).

[34] ABNT (Brazilian Association of Technical Standards), NBR 7222: mortar and concrete - determination of the tension strength of cylindrical specimens submitted to diametrical compression - method of test. Rio de Janeiro, 1994. 3p. (in portuguese). 
[35] NBN (Bureau de Normalisation) NBN B 15-238 - essais des bétons renforcés de fibres - essai de flexion sur éprouvettes prismatiques, 2002.

[36] G. Görhan, The evaluation with anova of the effect of lime admixture and thermal cure time on fly ash paste activated with sodium silicate solution Constr. Build. Mater. 94 (2015) 228-234.

[37] A. Kavussi, M. Gorbani, A. Khodaii, H.F. Haghshenas, Moisture susceptibility of warm mix asphalt: a statistical analysis of the laboratory testing results. Constr. Build. Mater. 52 (2014) 511-517.

[38] W.W. Hines, D.C. Montgomery, D.M. Goldsman,C.M. Borror, Probability and statistics in engineering. Edited by Wiley. 672 pages, 2003.

[39] ABNT (Brazilian Association of Technical Standards), NBR 14859-2: prefabricated slab - requirements part 2: bi-directional slabs. Rio de Janeiro, 2002. (in portuguese).

[40] D.O.J. Santos, Utilização de areia artificial em matrizes para fibrocimento ambiental/UEFS, 2014.

[41] M.E.D. Oliveira, Agregado reciclado de construção e demolição: influência em propriedades de argamassas para revestimento. (M. Sc. Thesis) Programa de pós graduação em engenharia civil e ambiental/UEFS, 2012.

[42] J.A. Melo Filho, Durabilidade química e térmica e comportamento mecânico de compósitos de alto desempenho reforçados com fibras de sisal. (Phd Thesis) COPPE/UFRJ, 2012.

[43] C. Neno, J. Brito, R, Veiga, Using fine recycled concrete aggregate for mortar production. Mater. Res. 17 (2013) 168-177.

[44] V. Corinaldesi, M. Giuggiolini, G. Moriconi, Use of rubble from building demolition in mortars, Waste Management, 22(8) (2002) 893-899.

[45] P.R.L. Lima, R.D. Toledo Filho, J.A. Melo Filho, Compressive stress-strain behaviour of cement mortar-composites reinforced with short sisal fibre. Mater. Res. 17 (1) (2104) 38-46.

[46] L.C. Bank, A.P. Malla, M.G. Oliva, J.S. Russell, A. Bentur, A. Shapira, A model specification for fiber reinforced non-participating permanent formwork panels for concrete bridge deck construction, Constr. Build. Mater. 23(7) (2009) 2664-2677.

[47] A. Ventura-Gouveia, J.A.O. Barros, A.F.M. Azevedo, Crack constitutive model for the prediction of punching failure modes of fiber reinforced concrete laminar structures, Comput. Concrete. 8(6) (2011) 735-755.

852 [48] I.S. Izquierdo, O.S. Izquierdo, M.A. Ramalho, A. Taliercio, Sisal fiber reinforced 853 hollow concrete blocks for structural applications: testing and modeling. Constr. Build. 854 Mater. 151 (2017) 98-112.

[49] J.M. Sena-cruz, Strengthening of concrete structures with near-surface mounted CFRP laminate strips (Phd Thesis) University of Minho, 2004. 